Enzymatic Hydrolysis of Heat-induced Aggregates of Whey Protein Isolate I.B. O’Loughlin, B.A. Murray, P.M. Kelly, R.J. FitzGerald, A. Brodkorb

This article is provided by the author(s) and Teagasc T-Stór in accordance with publisher policies.

Please cite the published version.

The correct citation is available in the T-Stór record for this article.

NOTICE: This document is the Accepted Manuscript version of a Published Work that appeared in final form in the Journal of Agricultural and Food Chemistry, copyright (C) American Chemical Society after peer review and technical editing by the publisher. To access the final edited and published work see Journal of Agricultural Food Chemistry 60(19), 4895-4904. 2012 . DOI: 10.1021/jf205213n

This item is made available to you under the Creative Commons Attribution-Non commercial-No Derivatives 3.0 License.

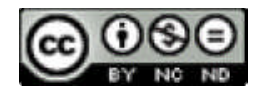




\section{Enzymatic Hydrolysis of Heat-induced Aggregates of Whey Protein Isolate}

I.B. O’Loughlin ${ }^{1,2}$, B.A. Murray ${ }^{1}$, P.M. Kelly ${ }^{1}$, R.J. FitzGerald ${ }^{2}$, and A. Brodkorb ${ }^{1 *}$

${ }^{1}$ Teagasc Food Research Centre, Moorepark, Fermoy, Co. Cork, Ireland.

${ }^{2}$ Life Sciences Department, University of Limerick, Limerick, Ireland.

*Corresponding author,

Phone: +353-25-42222,

Fax +353-25-42340,

E-mail: andre.brodkorb@teagasc.ie 


\section{ABSTRACT}

The effects of heat induced denaturation and subsequent aggregation of Whey Protein Isolate (WPI) solutions on the rate of enzymatic hydrolysis was investigated. Denaturation of whey proteins was monitored by reversed-phase and size exclusion HPLC and observed by native- and SDS-PAGE. Treated and un-treated WPI solutions (100 $\mathrm{g} \mathrm{L}^{-1}$ protein) were hydrolysed to a target degree of hydrolysis $(\mathrm{DH})$ of $5 \%$ with Corolase $^{\circledR}$ PP. Aggregate formation was monitored using light microscopy, with size distribution determined by particle size. Viscosity and surface hydrophobicity exhibited large increases with heat-treatment and the major protein components in WPI showed differences in their rates of aggregation. Results revealed an increased rate of hydrolysis of protein solutions, which were subjected to a pre-hydrolysis heattreatment. Light and Confocal Laser Scanning Microscopy (CLSM) images illustrated the optical clarification of the solution, weakening of the gel network and disintegration of aggregates indicative of hydrolysis. Comparison of samples where there was a heat-treatment prior to hydrolysis and a control non-treated hydrolysis reaction, revealed significant differences in the time to reach $5 \% \mathrm{DH}(P<0.001)$. The heat-treatments $\geq 75{ }^{\circ} \mathrm{C}$ for 5 min produced significantly $(P<0.001)$ more rapid reactions than the other 5 heat-treatments and the control un-treated reaction. The viscosity, surface hydrophobicity, and insolubility of the heat-treated WPI solutions subsequently declined upon their hydrolysis. The extensive aggregation in some heattreated solutions was postulated to relate to the congruent increased rate of hydrolysis. This study demonstrated that prior thermal treatment of $\geq 75^{\circ} \mathrm{C}$ for 5 min can accelerate the enzymatic hydrolysis reaction of WPI with Corolase ${ }^{\circledR}$ PP. 


\section{INTRODUCTION}

Denaturation of globular proteins can provide an altered substrate for subsequent enzymatic hydrolysis. Detailed information on the contribution of thermal denaturation to substrate structure allows for a better understanding of the events taking place during the hydrolysis process.

The conformation adopted by a protein under a particular set of environmental conditions is a delicate balance between forces that promote and hinder un-folding, e.g., hydrophobic interactions (1). The physicochemical factors which affect protein aggregation are well documented. Globular proteins retain native conformation within a particular temperature range. Whey proteins, in particular, are sensitive to unfolding at temperatures above $60{ }^{\circ} \mathrm{C}(2)$. Whey protein conformational changes arising from heat-treatment may quickly progress to a point where aggregation takes place. The increased thermal motion of heated whey proteins in solution results in disruption of various intra- and intermolecular bonds and exposure of previously 'buried' hydrophobic residues to solvent $(3,4)$. Whey proteins, which have a large proportion of hydrophobic residues, conform structurally to a low surface area-to-volume ratio in order to minimise exposure of hydrophobic (apolar) residues to solvent.

Extended exposure to temperatures $>60{ }^{\circ} \mathrm{C}$ can irreversibly affect the solubility of whey proteins (2) and change the relative hydrophobicity at the protein surface leading to exposure of non-polar hydrophobic residues thereby increasing hydrophobic attraction. Hydrophobic interactions are reported to increase with increasing temperature up to $\sim 70{ }^{\circ} \mathrm{C}$, after which they diminish (1). Exposure of sulphydryl groups and hydrophobic patches due to unfolding decreases protein stability and as a result solubility $(5,6)$. 
The potential for interaction among the individual whey protein fractions during thermal treatments also needs to be taken into consideration. The individual fractions that constitute the whey proteins differ in their thermal stability in the order Ig $<$ BSA $<\beta$-lg $<\alpha$-la $<$ PP (7). While heating native $\alpha$-la on its own does not produce aggregates at temperatures $\leq 75^{\circ} \mathrm{C}$, free cysteine residues in $\beta$-lg and $\mathrm{BSA}$ lead to di-sulphide interchange reactions with other $\beta-\lg$ / BSA molecules and with $\alpha$ la (8). Unfolded proteins may be more susceptible to protein-protein interactions via calcium bridging in addition to hydrophobic bonding as well as disulphide interchange reactions (9).

The conformational state of a protein is known to affect its rate of proteolysis $(10,11)$. Native globular proteins assume a conformational state which may render them somewhat resistant to proteolysis. Heat-treatment of whey protein substrates has been shown to increase the rate of, or induce, proteolysis (12-14), as a result of protein unfolding and di-sulphide bond reduction (15). For example, native $\beta-\lg$ is resistant to hydrolysis by pepsin, however, heat-treatment of $\beta$-lg at $82{ }^{\circ} \mathrm{C}$ results in peptic hydrolysis (12). The exposure of hydrophobic residues can lead to greater reactivity (4) and heat-denatured whey proteins can be readily solubilised during hydrolysis (16).

It is noteworthy that not all thermal-treatments result in an increase in hydrolytic susceptibility $(17,18)$. Pre-heating of $\alpha$-la at $95{ }^{\circ} \mathrm{C}$ for 10 min resulted in reduced hydrolysis activity with Pronase ${ }^{\circledR}$, trypsin and pancreatin activities (17). This highlights the inter-dependence of pre-treatment and of substrate conformation with the rate of hydrolysis.

While the choice of protease and the degree of hydrolysis are major determining factors in hydrolysate physico-chemical properties, the function of pre- 
hydrolysis heat-treatments in altering these parameters requires clarification. The objective of this study was to investigate the role of thermal aggregation on the hydrolysis of Whey Protein Isolate (WPI) with Corolase ${ }^{\circledR} \mathrm{PP}$ a food-grade porcine pancreatic proteolytic preparation. A novel approach employed herein was the use of macrostructure imaging techniques to characterise changes in protein aggregate structures during the course of enzymatic hydrolysis.

\section{MATERIALS AND METHODS}

\section{Materials}

Whey Protein Isolate (Isolac ${ }^{\circledR}$ ) was provided by Carbery Food Ingredients, (Ballineen, Co. Cork, Ireland). The powder contained $89.3 \%(\mathrm{w} / \mathrm{w})$ protein by Kjeldahl $[N \times 6.38,(19)]$ comprising $56.5 \% \beta$-lactoglobulin, $14.3 \% \alpha$-lactalbumin, $10.3 \%$ glycosylated caseinomacropeptide (CMP), $8.0 \%$ non-glycosylated CMP, 1.3 $\%$ lactoferrin (LF) and $1.7 \%$ bovine serum albumin (BSA). Denatured material amounted to $15.4 \%$ of total protein as determined by urea-denaturing RP-HPLC (20).

The digestive-enzyme complex Corolase ${ }^{\circledR}$ PP (E.C. 3.4.21.4.) was from $A B$ Enzymes GmbH (Darmstadt, Germany), and has a minimum activity of 220,000 Lohlein-Volhard Units $\mathrm{g}^{-1}$ at $\mathrm{pH}$ 8. Corolase ${ }^{\circledR} \mathrm{PP}$ possesses chymotrypsin, elastase and tryptic activities as well as aminopeptidase, along with carboxypeptidase A1, A2 and B exopeptidase activities (21). Corolase ${ }^{\circledR} \mathrm{PP}$ also contains dipeptidase activity and the optimum $\mathrm{pH}$ for overall activity is 8.0 (AB Enzymes).

Dialysis membranes (molecular wt. cut off 3500Da) and acetonitrile were purchased from ThermoFisher Scientific (Waltham, MA, USA). All further chemicals were analytical grade and were purchased from Sigma-Aldrich (Dublin, Ireland). 


\section{Heat treatment of WPI solutions}

WPI solutions (20 mL, $100 \mathrm{~g} \mathrm{~L}^{-1}$ protein, $\mathrm{pH}$ 6.4) were subjected to selected heat-treatments over a range of temperatures from $60{ }^{\circ} \mathrm{C}$ to $80{ }^{\circ} \mathrm{C}$ for selected time periods i.e., 5, 10 and $15 \mathrm{~min}$. The specific temperature $\left({ }^{\circ} \mathrm{C}\right) \mathrm{x}$ time $(\mathrm{min})$ treatments were as follows; $60 \times 15,65 \times 5,65 \times 15,70 \times 5,70 \times 15,75 \times 5,75 \times 15$, and $80 \times$ 10. Samples were solubilised in de-ionised water and allowed to hydrate overnight at $4{ }^{\circ} \mathrm{C}$. Heat-treatments were performed in triplicate in a thermostatically controlled water bath. At the end of each treatment solutions were placed in ice/water bath. Lyophilised powders were stored in a cool low moisture environment.

\section{Chromatographic characterisation of control and heated-treated WPI solutions}

High performance liquid chromatography (HPLC) was carried out using a Waters 2695 separation module, a Waters 2487 dual wavelength absorbance detector running on Waters Empower ${ }^{\circledR}$ software (Milford, MA, USA). Reversed-phase (RP) HPLC was used to observe the loss in native protein using a Source ${ }^{\mathrm{TM}} 5 \mathrm{RPC}, 150 \mathrm{~mm}$ x $4.6 \mathrm{~mm}$, column (GE Healthcare, Buckinghamshire, UK). Solvent A was $0.1 \%$ trifluoroacetic acid (TFA) in MilliQ water and Solvent B was 90\% HPLC-grade acetonitrile $(\mathrm{MeCN})$ containing $0.1 \%$ TFA in MilliQ water. Gradient elution conditions were as follows; Solvent B: $20 \%$ to $40 \%$ in $10 \mathrm{~min}, 40 \%$ to $60 \%$ in $20 \mathrm{~min}$, 60 to $100 \%$ in $5 \mathrm{~min}, 100 \%$ for $3 \mathrm{~min}, 100$ to $20 \%$ in $3 \mathrm{~min}$, and $20 \%$ for $5 \mathrm{~min}$ at a flow-rate of $0.8 \mathrm{~mL} \mathrm{~min}^{-1}$. Protein solutions $\left(20 \mu \mathrm{L}, 2.5 \mathrm{~g} \mathrm{~L}^{-1}\right)$ were loaded onto the column which was equilibrated at $28{ }^{\circ} \mathrm{C}$. The column eluate was monitored at 214 nm. Proteins which possess the same retention time as procured non-heat treated standards under gradient elution were designated 'native'. These whey protein standards were $\alpha$-la, $\beta-\lg \mathrm{A}$ and $\mathrm{B}, \mathrm{BSA}$, lactoferrin, and CMP (Sigma-Aldrich, 
Dublin, Ireland) and all possessed less than $4 \%$ denatured material by ureadenaturing RP-HPLC (20). According to the methodology of Beyer and Kessler (1989), only native proteins would possess the identical retention time as these standards $(22,23)$. Changes in tertiary structure leading to a shift in retention time led to peaks being described as 'non-natively conformed'.

Not all 'non-native' proteins are involved in aggregation and size-exclusion chromatography (SEC) allowed for molecules with a molecular weight $\left(\mathrm{M}_{\mathrm{w}}\right)$ greater than that of the native protein to be designated as 'aggregates'. SEC was carried out on a TSK Gel G2000SW $\mathrm{XL}, 7.8 \mathrm{~mm}$ x $300 \mathrm{~mm}$, column (TosoHaas Bioscience $\mathrm{GmbH}$, Stuttgart, Germany) using an isocratic gradient of $20 \mathrm{mM}$ sodium phosphate buffer at $\mathrm{pH} 7$ at a flow-rate of $0.5 \mathrm{~mL} \mathrm{~min}^{-1}$ over $60 \mathrm{~min}$. Ribonuclease $\mathrm{A}$, Cytochrome C, Aprotinin, Bacitracin, His-Pro-Arg-Trp, Leu-Trp-Met-Arg, Bradykinin, Leu-Phe, and Tyr-Glu (Bachem AG, Bubendorf, Switzerland) were used as $\mathrm{M}_{\mathrm{w}}$ standards along with samples of the previously described whey protein standards. All chromatography test samples and standards were made up in MilliQ water $\left(2.5 \mathrm{~g} \mathrm{~L}^{-1}\right.$ solutions) pre-filtered through $0.45 \mu \mathrm{m}$ low protein binding membrane filters (Sartorius Stedim Biotech GmbH, Germany) and $20 \mu \mathrm{L}$ applied to the column. The column elute was monitored at $214 \mathrm{~nm}$ and all solvents were filtered under vacuum through $0.45 \mu \mathrm{m}$ high velocity filters (Millipore (UK) Ltd., Durham, UK).

\section{Electrophoresis}

Sodium dodecyl sulphate polyacrylamide gel electrophoresis (SDS-PAGE) was carried out using a modification of the method of Laemmli (24). SDS-PAGE of the heat-denatured WPI samples was carried out under reducing and non-reducing 
conditions. The acrylamide for the resolving gel $(15 \% \mathrm{w} / \mathrm{v})$ was prepared in $1.5 \mathrm{M}$ Tris- $\mathrm{HCl}$ buffer, $\mathrm{pH} 8.8$, with the stacking gel (4\% w/v) prepared in $0.5 \mathrm{M}$ Tris- $\mathrm{HCl}$ buffer, $\mathrm{pH}$ 6.8. Samples were diluted to $3 \mathrm{~g} \mathrm{~L}^{-1}$ in $0.5 \mathrm{M}$ Tris- $\mathrm{HCl}$ buffer. The addition of 2-mercaptoethanol for reducing samples was followed by heating at $95{ }^{\circ} \mathrm{C}$ for 5 $\min$.

Native-PAGE gels were prepared using a modification of the method of Manderson et al. (25). Before pouring the gels, $50 \mu \mathrm{L}$ of ammonium persulphate solution $(10 \% \mathrm{w} / \mathrm{v})$ and $5 \mu \mathrm{L}$ of $N, N, N^{\prime}, N^{\prime}$-tetramethylethylenediamine (TEMED) were added to both the separating and stacking gel solutions. Test samples were diluted to $3 \mathrm{~g} \mathrm{~L}^{-1}$ in $0.5 \mathrm{M}$ Tris- $\mathrm{HCl}$ buffer.

For both SDS- and native-PAGE the samples were diluted $(1: 8 \mathrm{v} / \mathrm{v})$ in the respective sample buffers and run in a mini Protean II electrophoresis system (BioRad Alpha Technologies, Dublin, Ireland). For SDS-PAGE the running conditions were $155 \mathrm{~V}$ for $50 \mathrm{~min}$ and for native-PAGE the conditions were $180 \mathrm{~V}$ for $105 \mathrm{~min}$. Staining was with Coomassie Brilliant Blue R-250 in an acetic acid:isopropanol: $\mathrm{H}_{2} \mathrm{O}$ solution (3:10:17 by vol.) and gels were destained in an acetic acid:isopropanol: $\mathrm{H}_{2} \mathrm{O}$ solution (3:10:17 by vol.). Molecular weights were determined by comparison to a $\mathrm{M}_{\mathrm{w}}$ standard (Bio-Rad SDS-PAGE Standards - Low range, Bio-Rad, CA, USA). Imaging was accomplished with a Kodak Image Station 440 CF (Carestream Molecular Imaging, Woodbridge, CT, USA) with accompanying software.

\section{Particle size and surface hydrophobicity}

Particle size analysis was carried out using a Malvern ${ }^{\circledR}$ Mastersizer MSS (Malvern Instruments Ltd., Worcestershire, UK) running on Malvern ${ }^{\circledR}$ software. The Mastersizer was fitted with a He-Ne laser measuring at $633 \mathrm{~nm}$ and samples were 
dispersed in the Malvern ${ }^{\circledR}$ Hydro SM small volume sample dispersion unit $(225 \mathrm{x} 80 \mathrm{x}$ $180 \mathrm{~mm}$ ) with a maximum sample capacity of $120 \mathrm{~mL}$. The solutions were diluted in de-ionised water to give a laser obscuration of between 14 and $19 \%$ for optimal detection. Each sample was analysed in triplicate and the D. v 09 was presented herein. The D. v 09 is the representative diameter where $90 \%$ of the measured particles possess a diameter less than or equal to the stated value.

Surface hydrophobicity was determined using a modification of the method of Kato et al. (26). Samples of WPI were diluted in sodium dihydrogen phosphate dihydrate buffer (0.02 M, pH 6), with SDS (0.0404 $\left.\mathrm{g} \mathrm{L}^{-1}\right)$, and methylene blue (0.0240 $\left.\mathrm{g} \mathrm{L}^{-1}\right)$ solutions also prepared in the sodium phosphate buffer. WPI samples $\left(1 \mathrm{~g} \mathrm{~L}^{-1}\right)$ were mixed (1:2 v/v) with SDS solution and dialysed (MWCO 3.5kDa) against sodium dihydrogen phosphate dehydrate buffer $(1: 25)$ for $24 \mathrm{~h}$ at $20^{\circ} \mathrm{C}$. Mixtures of $0.5 \mathrm{~mL}$ of dialysate, $2.5 \mathrm{~mL}$ of methylene blue and $10 \mathrm{~mL}$ of chloroform were centrifuged at 2,500 $\mathrm{x} \mathrm{g}$ for $5 \mathrm{~min}$. The extinction of the chloroform phase was assessed at a wavelength of $655 \mathrm{~nm}$ according to the method of Hiller \& Lorenzen (27). Chloroform served as the solvent blank and a calibration curve was created for 0 $-100 \mu \mathrm{g}$ SDS. Surface hydrophobicity (SH) was then determined according to Eqn. 1. Analysis was carried out in duplicate.

$\mathrm{SH}(\mu \mathrm{g} \mathrm{SDS} / 500 \mu \mathrm{g}$ protein $)=($ Extinction $(\lambda=655 \mathrm{~nm})-0.0392) / 0.0178$

Where: 0.0392 and 0.0178 are derived from the calibration curve of SDS

\section{Solubility and turbidity}


For analysis of turbidity, samples $(500 \mu \mathrm{L})$ were diluted in $20 \mathrm{~mL}$ de-ionised water and the turbidity of the control, heat-treated and hydrolysate samples was determined by the optical density at $550 \mathrm{~nm}\left(\mathrm{OD}_{550}\right)$ using a Varian Cary ${ }^{\circledR} 1$ dual beam UV-visible spectrophotometer (Varian Ltd., Walton-on-Thames, UK). Optical density was measured at $550 \mathrm{~nm}$ so as to reduce the influence of the proteins on the absorbance of the incident light. For turbidity two aliquots of each replicate was analysed.

The solubility of WPI (100 $\mathrm{g} \mathrm{L}^{-1}$ protein, $\mathrm{pH}$ 6.4) solutions subjected to the heat-treatments outlined earlier and the subsequent hydrolysates was determined. Hydrolysates were adjusted to $\mathrm{pH} 6.4$ with $1 \mathrm{~N} \mathrm{HCl}$. All test samples were centrifuged at $1330 \mathrm{x} \mathrm{g}$ for $30 \mathrm{~min}$ at $20^{\circ} \mathrm{C}$ in an Eppendorf $5810 \mathrm{R}$ centrifuge (Eppendorf $\mathrm{AG}$, Hamburg, Germany). The supernatant was removed and filtered through Whatman no. 1 (Whatman International Ltd., Kent, UK) cellulose filter paper, after which protein concentration was determined by Kjeldahl ( $N$ x 6.38). Solubility was expressed as the amount of protein present in the supernatant relative to the total protein of the WPI prior to heat treatment $(\% \mathrm{w} / \mathrm{w})$. Solubility experiments were performed in duplicate.

\section{Enzymatic hydrolysis}

Degree of hydrolysis (DH) is the number of peptide bonds cleaved $(h)$ as a percentage of total peptide bonds $\left(h_{\mathrm{tot}}\right)$ and can be related to the consumption of base as hydrolysis releases protons by the following formula (28):

$\mathrm{DH} \%=100 \cdot B \cdot \mathrm{N}_{\mathrm{B}} \cdot(1 / \alpha) \cdot(1 / \mathrm{MP}) \cdot\left(1 / h_{\mathrm{tot}}\right)$ 
Where: $B$ is the volume of base, $\mathrm{N}_{\mathrm{B}}$ is the normality of the base, $1 / \alpha$ is the average degree of dissociation of $\alpha-\mathrm{NH}_{2}$ residues at $\mathrm{pH} 8$ and $50{ }^{\circ} \mathrm{C}$, MP is the mass of protein (g) and $h_{\text {tot }}$ is the total number of peptide bonds given in meq $\mathrm{g}^{-1}\left(N \times f_{\mathrm{N}}\right)$. The $h_{\mathrm{tot}}$ for whey protein concentrates is 8.8 .

For all hydrolysis experiments, $300 \mathrm{~mL}$ solutions of WPI $\left(100 \mathrm{~g} \mathrm{~L}^{-1}\right.$ protein, $\mathrm{pH}$ 8) were hydrolysed to a target degree of hydrolysis (DH) of $5 \%$ with Corolase ${ }^{\circledR}$ PP unless stated otherwise. Hydrolysis was performed at an enzyme:substrate (E:S) ratio of 1:100 (w/w) on a protein equivalent basis and the hydrolysis conditions were $50{ }^{\circ} \mathrm{C}$ and $\mathrm{pH} 8$, controlled throughout the reaction. The reaction was initiated by the addition of $10 \mathrm{~mL}$ of Corolase ${ }^{\circledR} \mathrm{PP}$ solution containing 0.3 g Corolase ${ }^{\circledR}$ PP giving a final E:S of $1 \%(w / w)$. The $\mathrm{pH}$ was controlled by titration with $2 \mathrm{~N} \mathrm{NaOH}$ using a Metrohm 842 Titrando dosing unit (Metrohm Ltd., Herisau, Switzerland) and the reaction was agitated utilising an over-head stirrer at $300 \mathrm{rpm}$. The reaction was terminated by heating the enzyme at $85^{\circ} \mathrm{C}$ for $20 \mathrm{~min}$. All hydrolysis experiments were conducted in triplicate.

For hydrolysis experiments performed at enzyme:substrate ratios of 0.5:100 $(0.5 \% \mathrm{w} / \mathrm{w}), 1 \%, 1.5 \%, 1.75 \%, 2 \%, 2.5 \%$, and $3 \%(\mathrm{w} / \mathrm{w})$ the hydrolysis conditions were the same as previously described.

\section{Rheological analysis}

Rheological analysis of heat-denatured WPI and hydrolysates of control and heat-denatured WPI was carried out using an AR G2 rheometer (TA Instruments, Crawley, UK), equipped with a starch pasting cell (cell diameter $36.00 \mathrm{~mm}$ ) complete with impeller, rotor diameter $32.40 \mathrm{~mm}$, rotor length $12.00 \mathrm{~mm}$ (TA Instruments, 
Crawley, UK). Samples (28 g, $100 \mathrm{~g} \mathrm{~L}^{-1}$ protein) were first pre-sheared at $16.57 \mathrm{rad} \mathrm{s}^{-1}$ for $1 \mathrm{~min}$ and equilibrated for $1 \mathrm{~min}$ at $25^{\circ} \mathrm{C}$. Samples were then sheared at a constant value of $16.57 \mathrm{rad} \mathrm{s}^{-1}$ and the viscosity measured after exactly $5 \mathrm{~min}$ of shearing. Rheological measurements of heat-denaturation of WPI were taken at intervals between 25 and $80{ }^{\circ} \mathrm{C}$. Un-heated control and heat-treated samples which were subjected to hydrolysis were also analysed rheologically. Samples (30 mL) were removed from the hydrolysis reaction vessel at designated time points and inactivated by bringing the $\mathrm{pH}$ to 2.5 with $2 \mathrm{~N} \mathrm{HCl}$. The apparent viscosity of these samples was then measured at $16.57 \mathrm{rad} \mathrm{s}^{-1}$ at $50{ }^{\circ} \mathrm{C}$ over $5 \mathrm{~min}$. All rheological measurements were carried out in triplicate.

\section{Light and confocal microscopy}

Light microscopy was performed utilising an Olympus BX51 (Olympus Ltd., Essex, UK) running on Image Access Premium ${ }^{\circledR} 8$ software. Samples from both the heat-denaturation and subsequent hydrolysis experiments were placed directly onto slides and aggregates were visualised and the mean length determined using the software (average of 20 samples was presented). Hydrolysis was followed in real-time by confocal laser scanning microscopy (CLSM) using a Leica TCS SP5 Confocal Scanning Laser Microscope (Leica Microsystems, Wetzler, Germany). Samples were prepared in $0.5 \mathrm{M}$ phosphate buffer in an indented rubber sealed slide complete with temperature control at $50^{\circ} \mathrm{C}$.

\section{Statistical analysis}

Analysis of variance (ANOVA) was performed through the use of Minitab 15 software (Minitab Inc., State College, PA, USA). This was followed by a Tukey test 
to determine the statistical difference of means where the significance level was established for $P<0.05$.

\section{RESULTS AND DISCUSSION}

\section{Characterisation of heat-denatured WPI}

Electrophoresis. Both SDS- and native-PAGE were utilised to characterise the nature of the inter-molecular interactions involved in the aggregation process (Fig. 1). This allowed determination as to whether the bonding occurring was through covalent or non-covalent interactions. In Fig. 1 the loss in band intensities for the major protein components in the WPI is shown by native- and non-reducing SDS-PAGE. NativePAGE (Fig. 1 A) showed that BSA, $\beta$-lg and $\alpha$-la bands decreased with increased intensity of heat-treatment. Unlike SDS-PAGE, where mobility depends primarily on molecular mass, in native-PAGE the mobility depends on both native charge and hydrodynamic size. For this reason $\alpha$-la does not traverse down the gel as much as $\beta$ $\lg A$ and $\beta-\lg B$ and this pattern has been shown previously for WPI (29). During native-PAGE, the aggregates formed on heat-treatment were too large to enter the gel. This is exhibited as a loss in band intensity for the whey proteins in Lanes $5\left(75^{\circ} \mathrm{C} \mathrm{x}\right.$ $15 \mathrm{~min})$ and $6\left(80{ }^{\circ} \mathrm{C} \times 10 \mathrm{~min}\right)$. Non-reducing SDS-PAGE (Fig. 1 B) showed a noticeable loss in the intensity of the bands for the whey proteins and the presence of high $\mathrm{M}_{\mathrm{w}}$ aggregates particularly in Lanes $6\left(75^{\circ} \mathrm{C}\right.$ x $\left.15 \mathrm{~min}\right)$ and $7\left(80^{\circ} \mathrm{C}\right.$ x $\left.10 \mathrm{~min}\right)$. This shows that aggregation was not entirely due to non-covalently linked aggregates as SDS breaks hydrophobic bonds. Less whey proteins were present in the $80{ }^{\circ} \mathrm{C} \times 10$ min heat-treated sample separated by native-PAGE (Lane 6, Fig. 1 A) when compared to non-reducing SDS-PAGE (Lane 7, Fig. 1 B). This denotes non-covalent interactions, such as hydrophobic aggregation, being present at the most intensive 
heat-treatments, namely $75^{\circ} \mathrm{C} \times 15 \mathrm{~min}$ and $80^{\circ} \mathrm{C}$ x $10 \mathrm{~min}$. The samples on reducing SDS-PAGE (Fig 1 C) gave similar band intensities across the different heattreatments, indicating that a high percentage of the aggregation in the WPI was the result of covalently linked di-sulphide interactions, which were reduced on treatment with 2-mercaptothanol.

Chromatography. The aggregates formed during heating of WPI represent a complex of proteins that possess differing heat resistances. RP-HPLC was used to determine whether the whey proteins were present in a native or denatured conformational state in the WPI following heat-treatment. In RP-HPLC, as the hydrophobicity changes due to thermally-induced unfolding and exposure of apolar residues, a loss in peaks corresponding to native proteins in WPI was observed. The loss in native $\alpha-\operatorname{la}, \beta-\lg \mathrm{A}, \beta-\lg \mathrm{B}$, and CMP (the proteins which constitute $\sim 79 \%$ of the total protein in the WPI) with increasing temperature and time treatment is shown in Fig. 2. CMP is a major component in WPI manufactured from cheese whey. The RP-HPLC data shows a relatively minor loss $\left(0.6 \pm 0.2 \mathrm{~g} \mathrm{~L}^{-1}\right)$ in native CMP concentration after a heat-treatment of $80{ }^{\circ} \mathrm{C}$ x $10 \mathrm{~min}$ in comparison to the un-heated control. This heat resistance has been attributed to the minimal structural features of CMP which is reported to exist as an essentially disorganised macro-peptide (31).

The concentration of native $\beta-\lg$ A declined from $17.2 \pm 0.2 \mathrm{~g} \mathrm{~L}^{-1}$ in control un-heated WPI to $4.0 \pm 0.5 \mathrm{~g} \mathrm{~L}^{-1}$ on heat-treatment at $80^{\circ} \mathrm{C}$ x $10 \mathrm{~min}$. The differences in $\beta-\lg$ A concentration over the range of heat-treatments and also with respect to the control un-heated solutions was significant $(P<0.001)$. Figure 2 also shows a loss in native $\beta$ - $\lg \mathrm{B}$ from $16.7 \pm 0.1 \mathrm{~g} \mathrm{~L}^{-1}$ in control un-treated to $5.8 \pm 0.4 \mathrm{~g} \mathrm{~L}^{-1}$ after $80{ }^{\circ} \mathrm{C} \mathrm{x}$ 10 min treatment. The observed greater heat lability of $\beta-\lg A$ compared to $\beta-\lg B$ is in agreement with previous work (30). The rate of loss in native $\alpha$-la was lower than 
the loss in both native $\beta$-lg variants over the heat-treatments. The concentration of native $\alpha$-la decreased from $14.2 \pm 0.2 \mathrm{~g} \mathrm{~L}^{-1}$ to $5.1 \pm 0.5 \mathrm{~g} \mathrm{~L}^{-1}$ with the differences between the concentrations of native $\alpha$-la over the various heat-treatments being significant in comparison to each other and to the control $(P<0.001)$. Overall, the greatest incremental loss in total native protein concentration on heating occurred between $65^{\circ} \mathrm{C}$ x $15 \mathrm{~min}$ and $70{ }^{\circ} \mathrm{C}$ x 5 min.

Heat-denaturation of the proteins in the WPI solutions resulted in the loss of native proteins and extensive aggregation. SEC was utilised to distinguish the formation of aggregates. The aggregates produced on heat-treatment (Fig. 3 insert, Fig. $4 \mathrm{~B}$ and C) were greater than the exclusion limit of the guard column $(\sim 100 \mathrm{~nm})$ or were retained during sample filtration and as a result no discernable aggregates are observed by SEC (Fig. 3). The SEC profiles demonstrate that peaks corresponding to $\alpha-\operatorname{la}$ and $\beta-\lg$ were progressively reduced on heat-treatment. The peaks equivalent to CMP demonstrated that only $75^{\circ} \mathrm{C}$ x 15 min and WPI $80{ }^{\circ} \mathrm{C}$ x 10 min heat-treatments significantly reduced $(P<0.01)$ CMP concentration compared to the un-heated control. During SEC elution in $20 \mathrm{mM}$ sodium phosphate (pH 7) CMP exists in a multi-meric form having a molecular mass between 40 - $50 \mathrm{kDa}$ (Fig. 3). Hydrophobically complexed multi-meric forms of CMP above $\mathrm{pH} 4.5$ have been reported and this property has been exploited during CMP enrichment (32). Overall, the results from both RP-HPLC and SEC analysis indicate that CMP, in regards to concentration, is minimally involved in aggregation following heat-treatment of WPI, showing a relatively minor loss in concentration $(\sim 4 \%)$ at the highest heat-treatment.

Physicochemical characteristics of heat-treated samples. The relationship between particle size (by D.v 09 and light microscopy), turbidity $\left(\mathrm{OD}_{550}\right)$, solubility, viscosity and surface hydrophobicity were compared as a function of heat-treatments 
(see Table 1). The largest single increase in particle size (D.v 09) occurred between $65{ }^{\circ} \mathrm{C} \times 15 \min (16.6 \pm 0.2 \mu \mathrm{m})$ and $70{ }^{\circ} \mathrm{C} \times 5 \min (30.9 \pm 0.2 \mu \mathrm{m})$. This also coincided with the largest single decrease in overall native protein concentration (Fig. 2 and Table 1). The overall particle size increased from $15.9 \pm 0.4 \mu \mathrm{m}$ in the control un-heated WPI solutions to $40.2 \pm 0.6 \mu \mathrm{m}$ in the $80^{\circ} \mathrm{C} \times 10 \mathrm{~min}$ WPI solutions.

In this study visualisation of aggregate formation and morphology was accomplished with light microscopy (LM). Particle length measurements for the aggregates formed through heat-treatment were carried out with the accompanying software. Similar to the D.v 09 results, these measurements also showed the largest single increase in particle length between $65^{\circ} \mathrm{C}$ x $15 \min (17.5 \pm 2.3 \mu \mathrm{m})$ and $70{ }^{\circ} \mathrm{C} \mathrm{x}$ $5 \min (32.9 \pm 2.0 \mu \mathrm{m})$ heat-treatments of WPI. Figure $4(\mathrm{~A}-\mathrm{C})$ shows the increase in the extent of aggregation from un-heated control (Fig. 4 A) to $80^{\circ} \mathrm{C}$ x $10 \mathrm{~min}$ (Fig. 4 C). Heat-treatment above $65{ }^{\circ} \mathrm{C} \times 15 \mathrm{~min}$ resulted in white solutions (results not shown) and a corresponding increase in turbidity $\left(\mathrm{OD}_{550}\right)$, with the greatest increase occurring after heating at $80{ }^{\circ} \mathrm{C}$ x $10 \mathrm{~min}$ (Table 1). Heat-induced unfolding and subsequent aggregation led to insolubilisation, resulting in a reduction in solubility from $90 \pm 1 \%$ in the control un-heated solution to $31 \pm 2 \%$ solubility on heating at $80{ }^{\circ} \mathrm{C} \times 10$. The largest single decrease in solubility occurred for WPI heated at $70^{\circ} \mathrm{C}$ x $15 \min (71 \pm 2 \%)$ and $75^{\circ} \mathrm{C} \times 5 \min (56 \pm 2 \%)$. The high extent of insolubilisation at heat-treatments greater than $70{ }^{\circ} \mathrm{C}$ for 5 min meant that the solution of denatured WPI could only be kept in suspension through stirring. Rotational rheological analysis of the heat denatured WPI solutions (Table 1) demonstrated an increase in apparent viscosity from $15.5 \pm 0.4 \mathrm{mPa} \mathrm{s}^{-1}$ for un-heated control to $247.1 \pm$ $5.0 \mathrm{mPa} \mathrm{s}^{-1}$ for the $80^{\circ} \mathrm{C} \times 10 \mathrm{~min}$ heated samples. The largest single increase in 
viscosity was observed to occur on heating between $70{ }^{\circ} \mathrm{C}$ x $15 \mathrm{~min}\left(20.4 \pm 0.9 \mathrm{mPa} \mathrm{s}{ }^{-}\right.$ $\left.{ }^{1}\right)$ and $75^{\circ} \mathrm{C}$ x $5 \mathrm{~min}\left(118.4 \pm 3.1 \mathrm{mPa} \mathrm{s}^{-1}\right)$.

The surface hydrophobicity $(\mathrm{SH})$ of the protein solutions after dialysis was expressed as $\mu \mathrm{g}$ SDS bound per $500 \mu \mathrm{g}$ protein (Table 1). The disruption of hydrophobic interactions through binding of SDS facilitates movement of the cationic methylene blue dye into the chloroform phase (33). The SH of WPI increased by a factor of 4.75 on heating at $75^{\circ} \mathrm{C} \times 15 \mathrm{~min}$ (see Table 1). Interestingly, the $\mathrm{SH}$ decreased slightly to $70.11 \pm 2.01 \mu \mathrm{g}$ SDS / $500 \mu \mathrm{g}$ protein after $80{ }^{\circ} \mathrm{C} \times 10 \mathrm{~min}$ treatment of the WPI solutions, although this decrease was not significant $(P<0.05)$. These results were in agreement with the general trend of a previous study on a WPI (27). A loss in protein structure would theoretically increase the number of hydrophobic residues accessible (3) to the SDS-complex. A previous study demonstrated that during extensive aggregation $\mathrm{SH}$ may be expected to decrease if aggregates were linked via non-covalent hydrophobic interactions (34). However, the native- and SDS-PAGE results herein showed that a substantial degree of the aggregated material appeared to be linked covalently via di-sulphide linkages.

Rationale for physicochemical changes. Heating WPI at different temperature / time combinations led to the formation of aggregates giving functionally diverse solutions / suspensions from the un-heated control. Heating the WPI resulted in white, high turbidity solutions, with increased insolubility and viscosity. The reason for the large increase in viscosity may be due to the increased particle size and the heattreated insoluble whey proteins binding more water, which leads to an increase in apparent viscosity (35). The large aggregates, up to $40.2 \pm 0.6 \mu \mathrm{m}$ (D. v 09) were morphologically irregular when visualised by both light and confocal microscopy (Fig $4 C)$. 
Many contributing factors may hasten the onset of protein aggregation. According to the three stage denaturation model (36), the existence of some denatured protein prior to heat-treatment allows for the propagation of aggregation upon the application of heat. In our study, the presence of some particles having particle size values of $15.9 \pm 0.4 \mu \mathrm{m}$ (D. v 09) in the un-heated control may have influenced the formation of larger aggregates $(>30 \mu \mathrm{m})$ on heating at temperatures greater than 65 ${ }^{\circ} \mathrm{C}$. Furthermore, since the WPI preparation was obtained from rennet whey, the

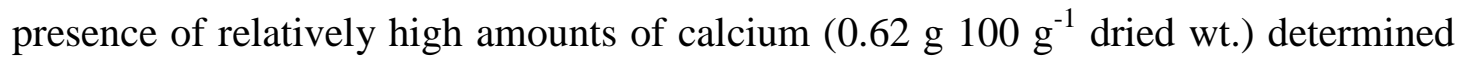
by the accepted IDF / ISO method (37), may induce electrostatic screening and accelerate the aggregation process $(5,38,39)$. In addition, the use of a relatively high protein concentration (100 $\mathrm{g} \mathrm{L}^{-1}$ protein) herein may also have promoted aggregation $(4,40)$.

\section{Enzymatic hydrolysis of control and heat-denatured WPI}

Influence on reaction rate. An increase in the rate of hydrolysis was observed in certain WPI solutions which were subjected to heat-treatment (Fig. 5). Previous studies have demonstrated improved reaction rates as a consequence of pre-treatment of whey protein substrates $(12,41)$. The time to reach a DH of $5 \%$ for a WPI solution subjected to pre-hydrolysis heat treatment of $80{ }^{\circ} \mathrm{C} \times 10 \mathrm{~min}(53 \pm 7 \mathrm{~min})$ was approximately half that of a un-heated control WPI solution (115 \pm 4 min). Heating WPI solutions $\left(100 \mathrm{~g} \mathrm{~L}^{-1}\right)$ to $80{ }^{\circ} \mathrm{C}$ for $10 \mathrm{~min}$ followed by hydrolysis, at an $\mathrm{E}: \mathrm{S}$ of 1:100, gave an equivalent reaction time to un-heated control WPI solutions $\left(100 \mathrm{~g} \mathrm{~L}^{-1}\right)$ hydrolysed at an E:S of 1.5:100 (Fig. 5 insert). Solutions which were subjected to prehydrolysis treatment at temperatures $\geq 75{ }^{\circ} \mathrm{C} \times 5 \mathrm{~min}$ had a statistically significant increased rate of hydrolysis $(P<0.001)$ compared to the un-heated control. A $72 \%$ 
loss in native protein concentration in WPI solutions heated at $80{ }^{\circ} \mathrm{C}$ for $10 \mathrm{~min}$ compared to the un-heated control resulted in a $54 \%$ decrease in hydrolysis time to achieve a DH of $5 \%$ (Fig. 5). Those samples subjected to heat-treatments; $60{ }^{\circ} \mathrm{C} \times 15$ $\min , 65^{\circ} \mathrm{C} \times 5 \mathrm{~min}, 65^{\circ} \mathrm{C} \times 15 \mathrm{~min}, 70^{\circ} \mathrm{C} \times 5 \mathrm{~min}$, and $70{ }^{\circ} \mathrm{C} \times 15 \mathrm{~min}$ displayed similar hydrolysis curves to control un-treated WPI and were not statistically different from the control hydrolysis reaction using the comparative Tukey test $(P<0.05)$. Therefore, the polymerisation of the whey proteins into aggregates $(\geq 36.9 \mu \mathrm{m})$ along with a total loss of native protein $\geq 41 \%$ presented a conformation which was beneficial to enzymatic hydrolysis with Corolase ${ }^{\circledR}$ PP.

Heat-denaturation of the WPI presumably exposes previously buried hydrolytic cleavage sites through structural changes in the whey proteins. Protein denaturation, which reduces tertiary and quaternary structure, reduces the ability of the protein to internalise and protect certain residues from hydrolytic cleavage (42). Denaturation of the polypeptide chain can result in a marked increase in the number of peptide bonds available for reaction (28). Adsorption and diffusion phenomena may also affect the rate of hydrolysis in irreversibly denatured protein (43) where large aggregates possess a much lower diffusion coefficient than the enzyme. However, this was minimised for our hydrolysis experiments which were performed under moderate stirring.

Physicochemical characteristics of hydrolysates. Table 2 summarises the physicochemical characteristics of the un-heat treated control, and the treatments showing the greatest increase in reaction rate (namely WPI $75^{\circ} \mathrm{C} \times 5 \mathrm{~min}, 75^{\circ} \mathrm{C} \times 15$ min, and $80^{\circ} \mathrm{C}$ x $10 \mathrm{~min}$ ) following hydrolysis with Corolase ${ }^{\circledR} \mathrm{PP}$. On hydrolysis to 5 $\%$ DH with Corolase ${ }^{\circledR} \mathrm{PP}$, particle size and turbidity were reduced in all the WPI solutions. This was especially the case for solutions subjected to the most extreme 
heat-treatments. The D.v 09 results show a $45.7 \%$ decrease in particle size on hydrolysis to $5 \% \mathrm{DH}$ of WPI $80^{\circ} \mathrm{C} \times 10 \mathrm{~min}$ (Table 2) compared to the un-hydolysed $80{ }^{\circ} \mathrm{C}$ x 10 min solution (Table 1). Table 2 also shows that hydrolysis of the most extensively heat-denatured WPI solutions, namely $75^{\circ} \mathrm{C}$ x $5 \mathrm{~min}, 75^{\circ} \mathrm{C}$ x $15 \mathrm{~min}$, and $80{ }^{\circ} \mathrm{C} \times 10 \mathrm{~min}$, resulted in an increase in solubility of the solution at $5 \% \mathrm{DH}$ compared to the respective un-hydrolysed samples (Table 1). The increase in solubility was greatest in the WPI $80{ }^{\circ} \mathrm{C}$ x 10 min hydrolysates, which showed an increase in solubility of $9 \pm 4 \%$ compared to the un-hydrolysed WPI $80{ }^{\circ} \mathrm{C} \times 10 \mathrm{~min}$ heat-treated substrate prior to hydrolysis.

The changes in apparent viscosity taking place during hydrolysis of un-heated control and heat-treated solutions of WPI samples was monitored though rotational rheological analysis. Over the course of the hydrolysis reaction the mean apparent viscosity of the WPI non-heat treated control solution decreased; from $1.61 \pm 0.69 \mathrm{x}$ $10^{-2} \mathrm{~Pa} / \mathrm{s}$ at $0.2 \% \mathrm{DH}$ to $1.39 \pm 0.51 \times 10^{-2} \mathrm{~Pa} / \mathrm{s}$ at $5 \% \mathrm{DH}$. On the other hand, the apparent viscosity of the WPI $75^{\circ} \mathrm{C}$ x $5 \mathrm{~min}, 75^{\circ} \mathrm{C} \times 15 \mathrm{~min}$, and $80{ }^{\circ} \mathrm{C} \times 10 \mathrm{~min}$ solutions decreased significantly $(\mathrm{P}<0.001)$ at the $5 \% \mathrm{DH}$ level (Table 2$)$ compared to their un-hydrolysed equivalents (Table 1).

$\mathrm{SH}$ of the hydrolysates (Table 2) showed an increase in comparison to the respective un-hydrolysed starting solutions (Table 1). The greatest mean percentage increase in $\mathrm{SH}$ was $16.5 \%$ in the $80{ }^{\circ} \mathrm{C}$ x 10 min hydrolysate $(83.97 \pm 2.59 \mu \mathrm{g}$ SDS / $500 \mu \mathrm{g}$ protein) compared to the un-hydrolysed $80^{\circ} \mathrm{C}$ x $10 \mathrm{~min}$ solution $(70.11 \pm 2.01$ $\mu \mathrm{g}$ SDS / $500 \mu \mathrm{g}$ protein). This trend is in agreement with previous work on a heatdenatured WPI (42). However, peptide-protein hydrophobic interactions might have influenced the determinations. 
Microscopic analysis during the course of hydrolysis. Visualisation of the structural changes occurring in the WPI as a result enzymatic hydrolysis was achieved through microscopic analysis. In the solutions which were heat-treated prior to enzymatic hydrolysis it was possible to discern the destabilisation of aggregates by LM. Figure 4 D-F shows the changes in WPI heat-treated at $80{ }^{\circ} \mathrm{C} \times 10$ min during subsequent hydrolysis. Fig. 4 E shows the solution at $4.7 \% \mathrm{DH}\left(\mathrm{t}_{+50} \mathrm{~min}\right)$, where a noticeable reduction in the extent of aggregation is observed compared to Fig $4 \mathrm{D}\left(\mathrm{t}_{+2}\right.$ min). Allowing the enzymatic reaction to continue to $8.1 \% \mathrm{DH}$ (Fig $4 \mathrm{~F}$ ) reduced the extent of the aggregation leading to increased optical clarification. This was demonstrated by the fact that the turbidity $\left(0.21 \pm 0.03, \mathrm{OD}_{550}\right)$ at $8.1 \% \mathrm{DH}$ of the 80 ${ }^{\circ} \mathrm{C}$ x 10 min heat-treated solution was similar to the turbidity $\left(0.17 \pm 0.02, \mathrm{OD}_{550}\right)$ of a $65^{\circ} \mathrm{C}$ x 5 min heat-treated solution pre-hydrolysis.

Hydrolysis was also followed in situ using CLSM where the WPI solution (100 $\mathrm{g} \mathrm{L}^{-1}$ protein) was stained with acridine orange. A previous study (44) utilised microscopy (TEM) to visualise the structural differences of $\beta$-lg pre- and posthydrolysis with pepsin. In our study, a novel method for determining aggregate disintegration was presented through the use of a sealed-cell in CLSM which allowed for the hydrolysis reaction to be followed 'real-time'. From the CLSM images (Fig. 6) the formation of morphologically irregular aggregates is apparent in the hydrolysed WPI subjected to pre-heating at $80^{\circ} \mathrm{C}$ for $10 \mathrm{~min}$. In Fig. $6 \mathrm{~A}$ the aggregates appear to be quite regularly distributed after $5 \mathrm{~min}$ of hydrolysis. However, large gaps began to appear as hydrolysis proceeds and an aggregate network began to form (Fig. 6B and 6C) as aggregate size was reduced (Table 2) from $40.17 \pm 0.63 \mu \mathrm{m}$ (Table 1) at time zero to $22.10 \pm 0.47 \mu \mathrm{m}$ after 50 min hydrolysis (results not shown). 
Conclusion. Aggregation of WPI by thermal pre-treatment allowed for improved susceptibility to hydrolysis with Corolase ${ }^{\circledR}$ PP. This improvement was most marked in WPI solutions which had been subjected to a heat-treatment $\geq 75{ }^{\circ} \mathrm{C}$ for 5 min. This study showed how different heat-treatments changed the structural characteristics of the substrate at the individual protein level along with the associated changes in their functional attributes, e.g. solubility. Utilising various analytical techniques allowed for the quantification and visualisation of the changes taking place both as a result of heat-treatment and during the course of subsequent hydrolysis. The use of both light and confocal microscopy offered a new approach for monitoring enzymatic hydrolysis of food proteins.

\section{ACKNOWLEDGEMENTS}

The authors wish to acknowledge the help and assistance gratefully provided by the staff of the National Food Imaging Centre, Moorepark, Fermoy, Ireland, especially M. A. Auty.

\section{LITERATURE CITED}

1. Bryant, C. M.; McClements, D. J., Molecular basis of protein functionality with special consideration of cold-set gels derived from heat-denatured whey. Trends in Food Science and Technology 1998, 9, 143-151.

2. deWit, J.; Klarenbeek, G., Effects of Various Heat Treatments on Structure and Solubility of Whey Proteins. J. Dairy Sci. 1984, 67, 2701-2710.

3. Boye, J. I.; Ma, C. Y.; Harwalker, V. R., Thermal denaturation and coagulation of proteins. In Food Proteins and their Applications, Damodaran, S., Paraf, A.,, Ed. Marcell Dekker Inc.: New York, 1997; pp 25-56. 
4. Singh, H.; Havea, P., Thermal denaturation, aggregation and gelation of whey proteins. In Advanced Dairy Chemistry - Proteins Part B, 3rd ed.; Fox, P. F.;

McSweeney, P. L. H., Eds. Kluwer Academic / Plenum Publishers: New York, 2003; Vol. 1.

5. Dickenson, E.; McClements, D. J., Advances in Food Colloids. 1st ed.; Blackie Academic and Professional: Glasgow, UK. , 1995; p 27-80.

6. Sava, N.; Rotaru, G.; Hendrickx, M., Heat-induced changes in solubility and surface hydrophobicity of $\beta$-lactoglobulin. Journal of Agroalimentary Processes and Technologies 2005, 11, 41-48.

7. Donovan, M.; Mulvihill, D. M., Thermal Denaturation and Aggregation of Whey Proteins. Irish Journal of Food Science and Technology 1987, 11, (1), 87-100. 8. Gezimati, J.; Creamer, L. K.; Singh, H., Heat-Induced Interactions and Gelation of Mixtures of $\beta$-Lactoglobulin and $\alpha$-Lactalbumin. J. Agric. Food Chem. 1997, 45, (4), 1130-1136.

9. Havea, P.; Singh, H.; Creamer, L. K.; Campanella, O. H., Electrophoretic characterization of the protein products formed during heat treatment of whey protein concentrate solutions. Journal of Dairy Research 1998, 65, 79-91.

10. Green, N. M.; Neurath, H., Proteolytic enzymes. In The Proteins, Volume 11 Part B, Neurath, H., Bailey, K., Ed. Academic Press: New York, 1954; pp 1057-1198. 11. Miranda, G.; Hazé, G.; Scanff, P.; P., P. J., Hydrolysis of $\alpha$-lactalbumin by chymosin and pepsin. Effect of conformation and pH. Lait 1989, 69, 451-459.

12. Schmidt, D. G.; van Markwijk, B. W., Enzymatic hydrolysis of whey proteins - Influence of heat treatment of $\alpha$-lactalbumin and $\beta$-lactoglobulin on their proteolysis by pepsin and papain. Netherlands Milk and Dairy Journal 1993, 47, 15-22. 
13. Mullally, M. M.; Meisel, H.; FitzGerald, R. J., Angiotensin-I-converting enzyme inhibitory activities of gastric and pancreatic proteinase digests of whey proteins. International Dairy Journal 1997, 7, (5), 299-303.

14. Kim, S. B.; Ki, K. S.; Khan, M. A.; Lee, W. S.; Lee, H. J.; Ahn, B. S.; Kim, H. S., Peptic and Tryptic Hydrolysis of Native and Heated Whey Protein to Reduce Its Antigenicity. J. Dairy Sci. 2007, 90, (9), 4043-4050.

15. Reddy, I. M.; Kella, N. K. D.; Kinsella, J. E., Structural and conformational basis of the resistance of .beta.-lactoglobulin to peptic and chymotryptic digestion. $J$. Agric. Food Chem. 1988, 36, (4), 737-741.

16. Monti, J. C.; Jost, R., Enzymatic solubilisation of heat denatured cheese whey protein. J. Dairy Sci. 1978, 61, 1233-1287.

17. Schmidt, D. G.; Poll, J. K., Enzymatic hydrolysis of whey proteins. Hydrolysis of $\alpha$-lactalbumin and $\beta$-lactoglobulin in buffer solutions by proteolytic enzymes. Netherlands Milk and Dairy Journal 1991, 45, 225-240.

18. Anema, S. G.; Lee, S. K.; Klostermeyer, H., Effect of $\mathrm{pH}$ at heat treatment on the hydrolysis of $\kappa$-casein and the gelation of skim milk by chymosin. $L W T$ - Food Science and Technology 2007, 40, 99-106.

19. Merrill, A. L.; Watt, B. K., Energy Value of Foods : Basis and Derivation. In Agriculture Handbook No 74, United States Government Printing Office: Washington, 1973; p 4.

20. Visser, S.; Slangen, C. J.; Rollema, H. S., Phenotyping of bovine milk proteins by reversed-phase high-performance liquid chromatography. Journal of Chromatography A 1991, 548, (0), 361-370.

21. Mullally, M. M.; O'Callaghan, D. M.; FitzGerald, R. J.; Donnelly, W. J.; Dalton, J. P., Proteolytic and Peptidolytic Activities in Commercial Pancreatic 
Protease Preparations and Their Relationship to Some Whey Protein Hydrolyzate Characteristics. J. Agric. Food Chem. 1994, 42, (12), 2973-2981.

22. Tolkach, A.; Steinle, S.; Kulozik, U., Optimisation of thermal pretreatment conditions for the separation of native $\alpha$-lactalbumin from whey protein concentrates by means of selective denaturation of $\beta$-lactoglobulin. J. Food Sci. 2005, 70, 566-577. 23. Beyer, H. J.; Kessler, H. G., Bestimmung des thermischen denaturierungverhaltens von molkenproteinen mittels HPLC. GIT Supplement Lebensmittel 1989, 2, 22-24.

24. Laemmli, U. K., Cleavage of structural proteins during the assembly of the head of bacteriophage T4. Nature 1970, 227, (5259), 680-685.

25. Manderson, G. A.; Hardman, M. J.; Creamer, L. K., Effect of Heat Treatment on the Conformation and Aggregation of $\beta$-Lactoglobulin A, B, and C. J. Agric. Food Chem. 1998, 46, (12), 5052-5061.

26. Kato, A.; Matsuda, T.; Matsudomi, N.; Kobayashi, K., Determination of protein hydrophobicity using a sodium dodecyl sulphate binding method. J. Agric. Food Chem. 1984, 32, 284-288.

27. Hiller, B.; Lorenzen, P. C., Surface hydrophobicity of physiochemically and enzymatically treated milk proteins in relation to techno-functional properties. $J$. Agric. Food Chem. 2008, 56, 461-468.

28. Adler-Nissen, J., Enzymatic Hydrolysis of Food Proteins 1986, (Elsevier Applied Science Publishers Ltd, New York).

29. Glibowski, P.; Mleko, S.; Wesolowska-Trojanowska, M., Gelation of single heated vs. double heated whey protein isolate. International Dairy Journal 2006, 16, (9), 1113-1118. 
30. Nielsen, B. T.; Singh, H.; Latham, J. M., Aggregation of bovine [beta]lactoglobulins A and B on heating at $75^{\circ} \mathrm{C}$. International Dairy Journal 1996, 6, (5), 519-527.

31. Smith, M. H.; Edwards, P. J.; nbsp; B; Palmano, K. P.; Creamer, L. K., Structural features of bovine caseinomacropeptide A and B by $1 \mathrm{H}$ nuclear magnetic resonance spectroscopy. Journal of Dairy Research 2002, 69, (01), 85-94.

32. Tanimoto, M.; Kawasaki, Y.; Dosako, S.; Ahiko, K.; Nakajima, I., Large-scale preparation of kappa-casein glycomacropeptide rennet casein whey. Bioscience, Biotechnology, and Biochemistry 1992, 56, 140-141.

33. Epton, S., A new method for the rapid titrimetric analysis of sodium alkyl sulphates and related compounds. Transactions of the Faraday Society 1948, 44, 226230.

34. Laligant, A.; Dumay, E.; Casas Valencia, C.; Cuq, J. L.; Cheftel, J. C., Surface hydrophobicity and aggregation of .beta.-lactoglobulin heated near neutral $\mathrm{pH} . J$. Agric. Food Chem. 1991, 39, (12), 2147-2155.

35. Morr, C. V., Beneficial and Adverse Effects of Water-Protein Interactions in Selected Dairy Products. J. Dairy Sci. 1989, 72, (2), 575-580.

36. Steventon, A. J.; Gladden, L. F.; Fryer, P. J., A Percolation Analysis of the Concentration Dependence of the Gelation of Whey Protein Concentrates. Journal of Texture Studies 1991, 22, (2), 201-218.

37. Federation, I. D., Milk and milk products - determination of calcium, sodium, potassium and magnesium contents - atomic absorption spectrometric method. International Standard 8070 - IDF 1192007. 
38. Havea, P.; Singh, H.; Creamer, L. K., Heat-Induced Aggregation of Whey Proteins: Comparison of Cheese WPC with Acid WPC and Relevance of Mineral Composition. J. Agric. Food Chem. 2002, 50, (16), 4674-4681.

39. Barbut, S.; Foegeding, E. A., Ca2+-Induced Gelation of Pre-heated Whey Protein Isolate. J. Food Sci. 1993, 58, (4), 867-871.

40. Joly, M., A physico-chemical approach to the denaturation of proteins. In Molecular biology - An international series of monographs and text books, Academic Press: London and New York, 1965; Vol. 6.

41. Mullally, M. M.; Mehra, R.; FitzGerald, R. J., Thermal Effects on the Conformation and Susceptibility of $\beta$-Lactoglobulin to Hydrolysis by Gastric and Pancreatic Endoproteinases. Irish J. Agr. Food Res. 1998, 37, (1), 51-60.

42. Benyon, R., Oliver, S., Avoidance of Proteolysis in Extracts. Protein Purification Protocols 1996, 59, 81-93.

43. McLaren, A. D., Parker, L., Some aspects of enzyme reactions in heterogenous systems. Advanced Enzymology 1970, 33, 245-308.

44. Mudgal, P.; Daubert, C. R.; Clare, D. A.; Foegeding, E. A., Effect of Disulfide Interactions and Hydrolysis on the Thermal Aggregation of $\beta$-Lactoglobulin. J. Agric. Food Chem. 2010, 59, (5), 1491-1497.

\section{FINANCIAL SUPPORT}

The work herein was funded by Enterprise Ireland as part of the Food for Health Ireland project, grant number; CC20080001. I. B. O’Loughlin was funded by Enterprise Ireland under the Teagasc Walsh Fellowship Scheme. 
Figure 1. Electrophoresis of $100 \mathrm{~g} \mathrm{~L}^{-1}$ protein WPI solutions ( $\mathrm{pH}$ 6.4) subjected to different heat treatments: (A) Native-PAGE where; Lane (1) Unheated control, (2) $60^{\circ} \mathrm{C}$ for $15 \mathrm{~min}$, (3) $65^{\circ} \mathrm{C}$ for $15 \mathrm{~min}$, (4) $70^{\circ} \mathrm{C}$ for $15 \mathrm{~min},(5) 75^{\circ} \mathrm{C}$ for $15 \mathrm{~min}$, (6) $80^{\circ} \mathrm{C}$ for 10min. (B) Non-reducing SDS-PAGE and (C) Reducing SDS-PAGE. For both SDS-PAGE gels; Lane (1) marker, (2) Unheated control, (3) $60^{\circ} \mathrm{C}$ for $15 \mathrm{~min}$, (4) $65^{\circ} \mathrm{C}$ for $15 \mathrm{~min},(5) 70^{\circ} \mathrm{C}$ for $15 \mathrm{~min},(6) 75^{\circ} \mathrm{C}$ for $15 \mathrm{~min}$, (7) $80^{\circ} \mathrm{C}$ for $10 \mathrm{~min},(8)$ marker.

Figure 2. Native protein composition of $100 \mathrm{~g} \mathrm{~L}^{-1}$ untreated control and heat treated WPI solutions subjected to different temperature $\left({ }^{\circ} \mathrm{C}\right) \mathrm{x}$ time $(\mathrm{min})$ treatments determined by reversed phase-HPLC (sample mean $\pm \mathrm{SD}, \mathrm{n}=3$ ).

Figure 3. Reversed-phase chromatography of WPI (100 $\mathrm{g} \mathrm{L}^{-1}$ protein) solutions subjected to heat treatments. Where; (A) represents WPI unheated control, (B) WPI $75^{\circ} \mathrm{C}$ for $5 \mathrm{~min},(\mathrm{C}) \mathrm{WPI} 75^{\circ} \mathrm{C}$ for $15 \mathrm{~min}$ and (D) WPI $80{ }^{\circ} \mathrm{C}$ for $10 \mathrm{~min}$. Eluate was measured at $214 \mathrm{~nm}$.

Figure 3. Size exclusion chromatography of WPI (100 $\mathrm{g} \mathrm{L}^{-1}$ protein) solutions subjected to heat treatments. Where; ; represents WPI unheated control, ; intermediate heat treatments and, $\quad$; WPI $80^{\circ} \mathrm{C}$ for $10 \mathrm{~min}$. Samples were eluted with $20 \mathrm{mM}$ Na-Phosphate buffer. Insert is a confocal laser scanning microscopy image of an isolated WPI aggregate formed after heat treatment $\left(75^{\circ} \mathrm{C}\right.$ for $5 \mathrm{~min})$, where the black bar represents $15 \mu \mathrm{m}$.

Figure 4. Light microscope images of whey protein isolate (WPI) solutions (100 $\mathrm{g} \mathrm{L}^{-1}$ protein): (A) un-heated control, (B) heat-treated $70{ }^{\circ} \mathrm{C}$ for $15 \mathrm{~min}$, and (C) $80{ }^{\circ} \mathrm{C}$ for FINAL revised WORD version of O'Loughlin et al (2012). JAFC 60(19), 4895-4904. DOI: 10.1021/jf205213n 
10 min. Solution of $80{ }^{\circ} \mathrm{C}$ for 10 min treated WPI subsequently hydrolysed with Corolase $^{\circledR} \mathrm{PP}(1: 100 \mathrm{E}: \mathrm{S}) \mathrm{pH} 8$ at (D) $2 \mathrm{~min}(0.4 \% \mathrm{DH}),(\mathrm{E}) 50 \mathrm{~min}(4.7 \% \mathrm{DH})$ and (F) $130 \min (8.1 \% \mathrm{DH})$.

Figure 5. Hydrolysis profiles for whey protein isolate (100 $\mathrm{g} \mathrm{L}^{-1}$ protein, $\left.\mathrm{pH} 8\right)$ unheated control and heat treated solutions to a degree of hydrolysis (DH) of $5 \%$ with Corolase ${ }^{\circledR}$ PP (1:100 E:S) as obtained using the $\mathrm{pH}$-stat method. Where; $\diamond$ represents control, $\diamond$ represents $75^{\circ} \mathrm{C}$ for $5 \mathrm{~min}, \square_{\text {represents }} 75^{\circ} \mathrm{C}$ for $15 \mathrm{~min}$, and $\boldsymbol{\square}_{\text {represents }}$ $80{ }^{\circ} \mathrm{C}$ for $10 \mathrm{~min}$. Insert is of $100 \mathrm{~g} \mathrm{~L}^{-1}$ protein WPI solutions which were subjected to hydrolysis with varying concentrations of enzyme $(\diamond)$ and the time to reach a DH of 5 $\%$ was measured.

Figure 6. Confocal Laser Scanning Microscopy (CLSM) images of whey protein isolate $\left(100 \mathrm{~g} \mathrm{~L}^{-1}\right.$ protein) subjected to heating at $80{ }^{\circ} \mathrm{C}$ for $10 \mathrm{~min}$, stained with acridine orange, and subsequently hydrolysed with Corolase ${ }^{\circledR} \mathrm{PP}(1: 100 \mathrm{E}: \mathrm{S})$ at (A) 5 $\min (0.9 \% \mathrm{DH}),(\mathrm{B}) 30 \min (3.4 \% \mathrm{DH})$, and $(\mathrm{C}) 56 \min (5 \% \mathrm{DH})$. 
Table 1. Physicochemical characteristics of whey protein isolate $\left(100 \mathrm{~g} \mathrm{~L}^{-1}\right.$ protein, $\left.\mathrm{pH} 6.4\right)$ solutions subjected to varying temp $\left({ }^{\circ} \mathrm{C}\right) \mathrm{x}$ time (min) heat-treatments.

\begin{tabular}{|c|c|c|c|c|c|c|c|c|}
\hline \multirow[b]{2}{*}{ Test sample } & \multicolumn{4}{|c|}{ Particle size } & \multirow[b]{2}{*}{$\begin{array}{l}\text { Turbidity } \\
\mathrm{OD}_{550} a\end{array}$} & \multirow[b]{2}{*}{$\begin{array}{c}\text { Solubility } \\
(\%)\end{array}$} & \multirow{2}{*}{$\begin{array}{l}\text { Apparent } \\
\text { Viscosity } \\
\left(\mathrm{mPa} \mathrm{s}^{-1}\right)\end{array}$} & \multirow[b]{2}{*}{$\begin{array}{l}\text { Hydrophobicity } \\
\qquad b\end{array}$} \\
\hline & $\begin{array}{l}\text { D.v. } 09 \\
(\mu \mathrm{m})\end{array}$ & $\begin{array}{l}\text { D.v. } 05 \\
(\mu \mathrm{m})\end{array}$ & $\begin{array}{l}\text { D.v. } 01 \\
(\mu \mathrm{m})\end{array}$ & $\begin{array}{c}\mathrm{LM} \\
(\mu \mathrm{m})\end{array}$ & & & & \\
\hline WPI Control & $15.9 \pm 0.4^{\mathrm{x}}$ & $5.3 \pm 0.3^{x}$ & $0.5 \pm 0.3^{x}$ & $c$ & $0.04 \pm 0.01$ & $90 \pm 1$ & $15.5 \pm 0.4^{\mathrm{x}}$ & $15.53 \pm 1.27^{x}$ \\
\hline WPI $60^{\circ} \mathrm{C} \times 15 \mathrm{~min}$ & $16.4 \pm 0.3^{\mathrm{X}, \mathrm{Y}}$ & $5.5 \pm 0.4^{x}$ & $0.8 \pm 0.2^{\mathrm{x}}$ & $16.2 \pm 1.8^{x}$ & $0.11 \pm 0.02$ & $84 \pm 1^{x}$ & $15.6 \pm 0.8^{X, Y}$ & $17.17 \pm 1.50^{\mathrm{X}, \mathrm{Y}}$ \\
\hline WPI $65^{\circ} \mathrm{C} \times 5 \mathrm{~min}$ & $16.3 \pm 0.5^{\mathrm{X}, \mathrm{Y}}$ & $5.7 \pm 0.2^{x}$ & $0.6 \pm 0.4^{\mathrm{x}}$ & $17.4 \pm 1.6^{\mathrm{x}}$ & $0.17 \pm 0.02$ & $85 \pm 1^{x}$ & $15.6 \pm 0.9^{X, Y}$ & $20.37 \pm 1.94^{\mathrm{Y} Z}$ \\
\hline WPI $65^{\circ} \mathrm{C} \times 15 \mathrm{~min}$ & $16.6 \pm 0.2^{Y}$ & $5.6 \pm 0.3^{x}$ & $0.7 \pm 0.2^{\mathrm{x}}$ & $17.5 \pm 2.3^{x}$ & $0.29 \pm 0.07$ & $80 \pm 2^{Y}$ & $16.1 \pm 0.9^{X, Y}$ & $23.53 \pm 1.45^{z}$ \\
\hline WPI $70^{\circ} \mathrm{C}$ x $5 \mathrm{~min}$ & $30.9 \pm 0.2$ & $10.9 \pm 0.1^{\mathrm{Y}}$ & $1.4 \pm 0.3^{Y}$ & $32.9 \pm 2.0^{Y}$ & $0.41 \pm 0.05$ & $77 \pm 2^{Y}$ & $16.9 \pm 0.8^{Y}$ & $36.71 \pm 2.40$ \\
\hline WPI $70^{\circ} \mathrm{C} \times 15 \mathrm{~min}$ & $33.3 \pm 0.1$ & $11.2 \pm 0.4^{\mathrm{Y}}$ & $1.4 \pm 0.4^{\mathrm{Y}}$ & $35.0 \pm 1.8^{\mathrm{Y}, \mathrm{Z}}$ & $0.65 \pm 0.09$ & $71 \pm 2$ & $20.4 \pm 0.9$ & $51.97 \pm 3.30$ \\
\hline WPI $75^{\circ} \mathrm{C} \times 5 \mathrm{~min}$ & $36.8 \pm 0.4$ & $13.3 \pm 0.1^{\mathrm{z}}$ & $1.6 \pm 0.2^{\mathrm{Y}}$ & $38.6 \pm 2.5^{\mathrm{z}}$ & $0.95 \pm 0.13$ & $56 \pm 2$ & $118.4 \pm 3.1$ & $65.15 \pm 1.91$ \\
\hline WPI $75^{\circ} \mathrm{C} \times 15 \mathrm{~min}$ & $38.9 \pm 0.7$ & $13.8 \pm 0.5^{z}$ & $1.9 \pm 0.1^{\mathrm{Y}, \mathrm{Z}}$ & $44.6 \pm 3.2^{\mathrm{w}}$ & $1.86 \pm 0.20$ & $43 \pm 3$ & $214.9 \pm 6.7$ & $73.69 \pm 3.03^{w}$ \\
\hline WPI $80^{\circ} \mathrm{C}$ x $10 \mathrm{~min}$ & $40.2 \pm 0.6$ & $14.8 \pm 0.2$ & $2.2 \pm 0.3^{\mathrm{z}}$ & $45.7 \pm 4.7^{\mathrm{w}}$ & $>2$ & $31 \pm 2$ & $247.1 \pm 5.0$ & $70.11 \pm 2.01^{\mathrm{w}}$ \\
\hline
\end{tabular}

Same letters within a column; $\mathrm{x}, \mathrm{y}, \mathrm{z}, \ldots$ indicate insignificant differences $(\mathrm{P}>0.05)$.

${ }^{a}$ Optical density at $550 \mathrm{~nm}\left(\mathrm{OD}_{550}\right)$, protein solutions diluted to $2.5 \mathrm{~g} \mathrm{~L}^{-1}$ for absorbance $\leq 1$.

${ }^{b}$ Expressed as $\mu \mathrm{g}$ SDS bound per $500 \mu \mathrm{g}$ of protein.

${ }^{c}$ No aggregates accurately discerned with light microscopy (LM) $\leq 600 x$.

Error! Not a valid link. 
Table 2. Physicochemical characteristics of whey protein isolate (100 $\mathrm{g} \mathrm{L}^{-1}$ protein) and hydrolysed, to a degree of hydrolysis of $5 \%$ with

Corolase ${ }^{\circledR}$ PP (1:100 E:S)Error! Not a valid link., un-heated control and heat-treated solutions. Error! Not a valid link.

\begin{tabular}{|c|c|c|c|c|c|c|c|c|}
\hline \multirow[b]{2}{*}{ Test sample } & \multicolumn{4}{|c|}{ Particle size } & \multirow[b]{2}{*}{$\begin{array}{l}\text { Turbidity } \\
\mathrm{OD}_{550} a\end{array}$} & \multirow[b]{2}{*}{$\begin{array}{c}\text { Solubility } \\
(\%)\end{array}$} & \multirow{2}{*}{$\begin{array}{l}\text { Apparent } \\
\text { Viscosity } \\
\left(\mathrm{mPa} \mathrm{s}^{-1}\right) \\
\end{array}$} & \multirow[b]{2}{*}{$\begin{array}{l}\text { Hydrophobicity } \\
\qquad b \\
\end{array}$} \\
\hline & $\begin{array}{c}\text { D.v. } 09 \\
(\mu \mathrm{m})\end{array}$ & $\begin{array}{l}\text { D.v. } 05 \\
(\mu \mathrm{m})\end{array}$ & $\begin{array}{c}\text { D.v. } 01 \\
(\mu \mathrm{m})\end{array}$ & $\begin{array}{c}\mathrm{LM} \\
(\mu \mathrm{m})\end{array}$ & & & & \\
\hline WPI Control & $15.9 \pm 0.4$ & $5.3 \pm 0.3^{x}$ & $0.5 \pm 0.3^{x}$ & $c$ & $0.04 \pm 0.01^{\mathrm{x}}$ & $90 \pm 1^{\mathrm{x}}$ & $\begin{array}{l}\left(15.5 \pm 0.4^{\mathrm{x}}\right) d \\
16.1 \pm 0.2^{\mathrm{x}}\end{array}$ & $15.53 \pm 1.27^{x}$ \\
\hline \multicolumn{9}{|l|}{ Hydrolysates } \\
\hline WPI Control & $13.5 \pm 0.5$ & $4.8 \pm 0.3^{\mathrm{x}}$ & $0.7 \pm 0.2^{\mathrm{x}}$ & $c$ & $0.03 \pm 0.01^{\mathrm{x}}$ & $92 \pm 2^{\mathrm{x}}$ & $13.9 \pm 5.1^{\mathrm{x}}$ & $17.49 \pm 2.31^{\mathrm{x}}$ \\
\hline WPI $75^{\circ} \mathrm{C}$ x $5 \mathrm{~min}$ & $20.3 \pm 0.6^{\mathrm{x}}$ & $6.7 \pm 0.4^{\mathrm{Y}}$ & $1.0 \pm 0.4^{\mathrm{X}, \mathrm{Y}}$ & $21.4 \pm 2.8^{x}$ & $0.83 \pm 0.08^{\mathrm{Y}}$ & $59 \pm 2$ & $97.2 \pm 3.5^{\mathrm{Y}}$ & $73.06 \pm 2.63$ \\
\hline WPI $75^{\circ} \mathrm{C} \times 15 \mathrm{~min}$ & $20.2 \pm 0.4^{\mathrm{x}}$ & $7.0 \pm 0.2^{\mathrm{Y}}$ & $1.1 \pm 0.5^{\mathrm{X}, \mathrm{Y}}$ & $25.2 \pm 4.2^{\mathrm{x}}$ & $0.97 \pm 0.25^{\mathrm{Y}, \mathrm{Z}}$ & $50 \pm 3$ & $105.8 \pm 7.9^{\mathrm{Y}, \mathrm{Z}}$ & $81.72 \pm 1.66^{\mathrm{Y}}$ \\
\hline WPI $80^{\circ} \mathrm{C} \times 10 \mathrm{~min}$ & $21.8 \pm 0.5$ & $7.1 \pm 0.3^{\mathrm{Y}}$ & $1.2 \pm 0.3^{\mathrm{Y}}$ & $23.3 \pm 7.3^{x}$ & $1.26 \pm 0.24^{z}$ & $42 \pm 3$ & $113.1 \pm 7.4^{\mathrm{Z}}$ & $83.97 \pm 2.59^{Y}$ \\
\hline
\end{tabular}

\footnotetext{
${ }^{a}$ Optical density at $550 \mathrm{~nm}\left(\mathrm{OD}_{550}\right)$, protein solutions diluted to $2.5 \mathrm{~g} \mathrm{~L}^{-1}$ for absorbance $\leq 1$.

${ }^{b}$ Expressed as $\mu \mathrm{g}$ SDS bound per $500 \mu \mathrm{g}$ of protein.

${ }^{c}$ No aggregates accurately discerned with light microscopy $(\mathrm{LM}) \leq 600 \mathrm{x}$.

${ }^{d}$ Apparent viscosity determined at $\mathrm{pH}$ 6.4.
} 
Figure $1 \mathrm{~A}$

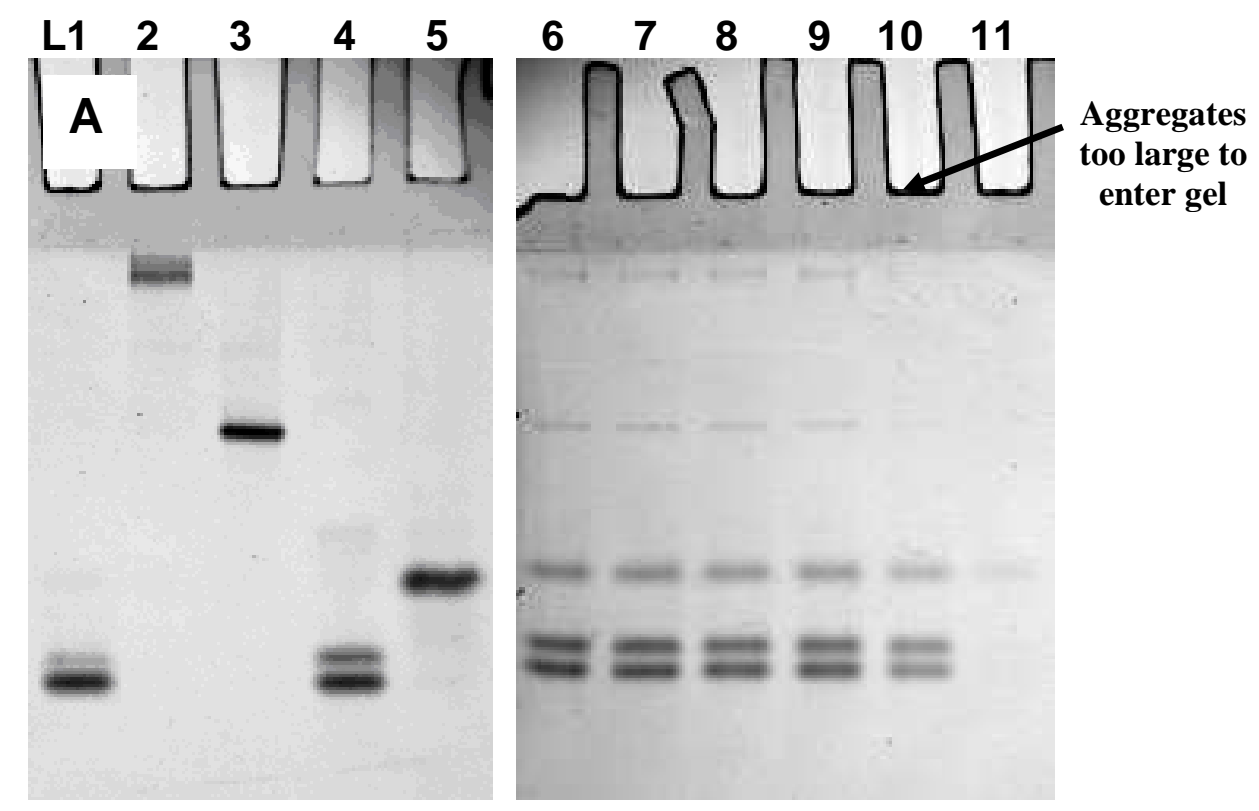


Figure 1 B

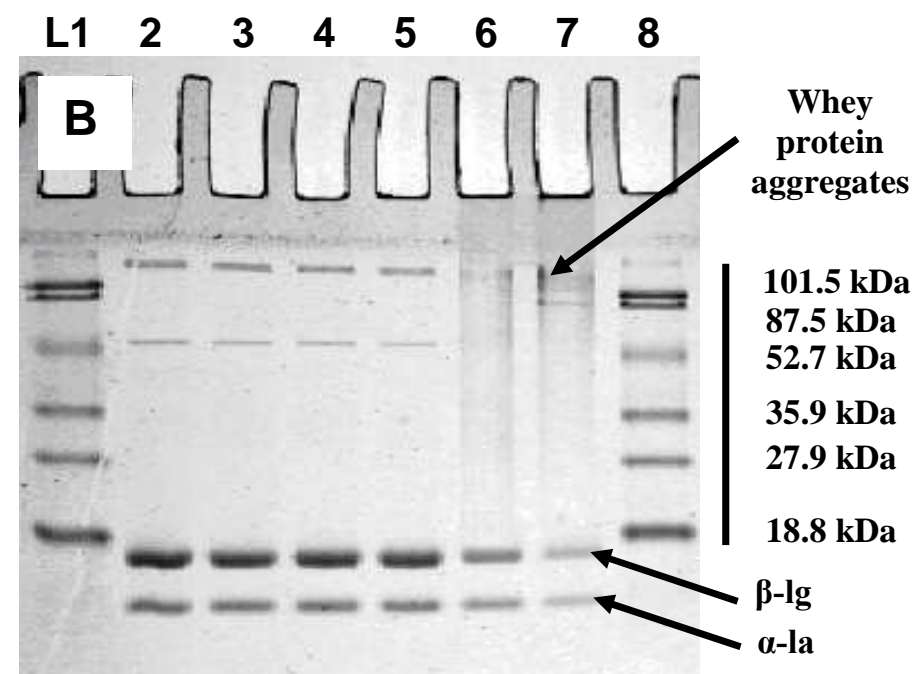

Figure $1 \mathrm{C}$

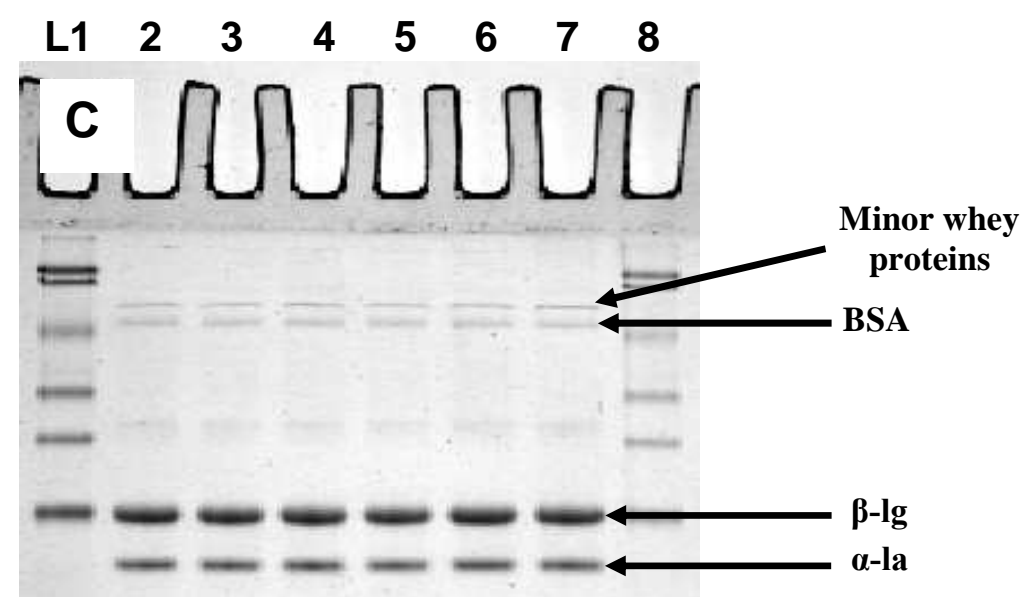


Figure 2

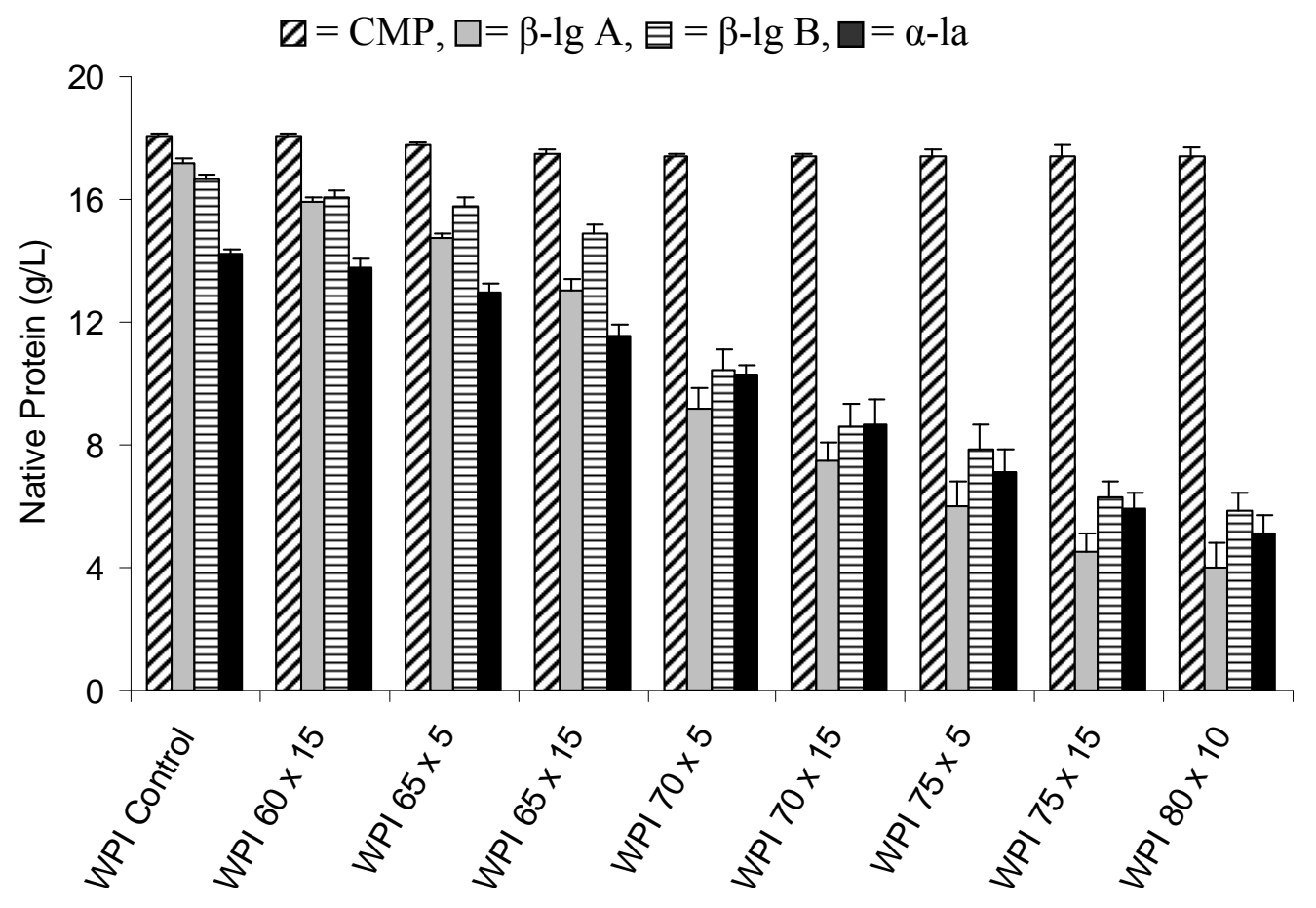

Figure 3 (intended for colour reproduction on-line and in print)

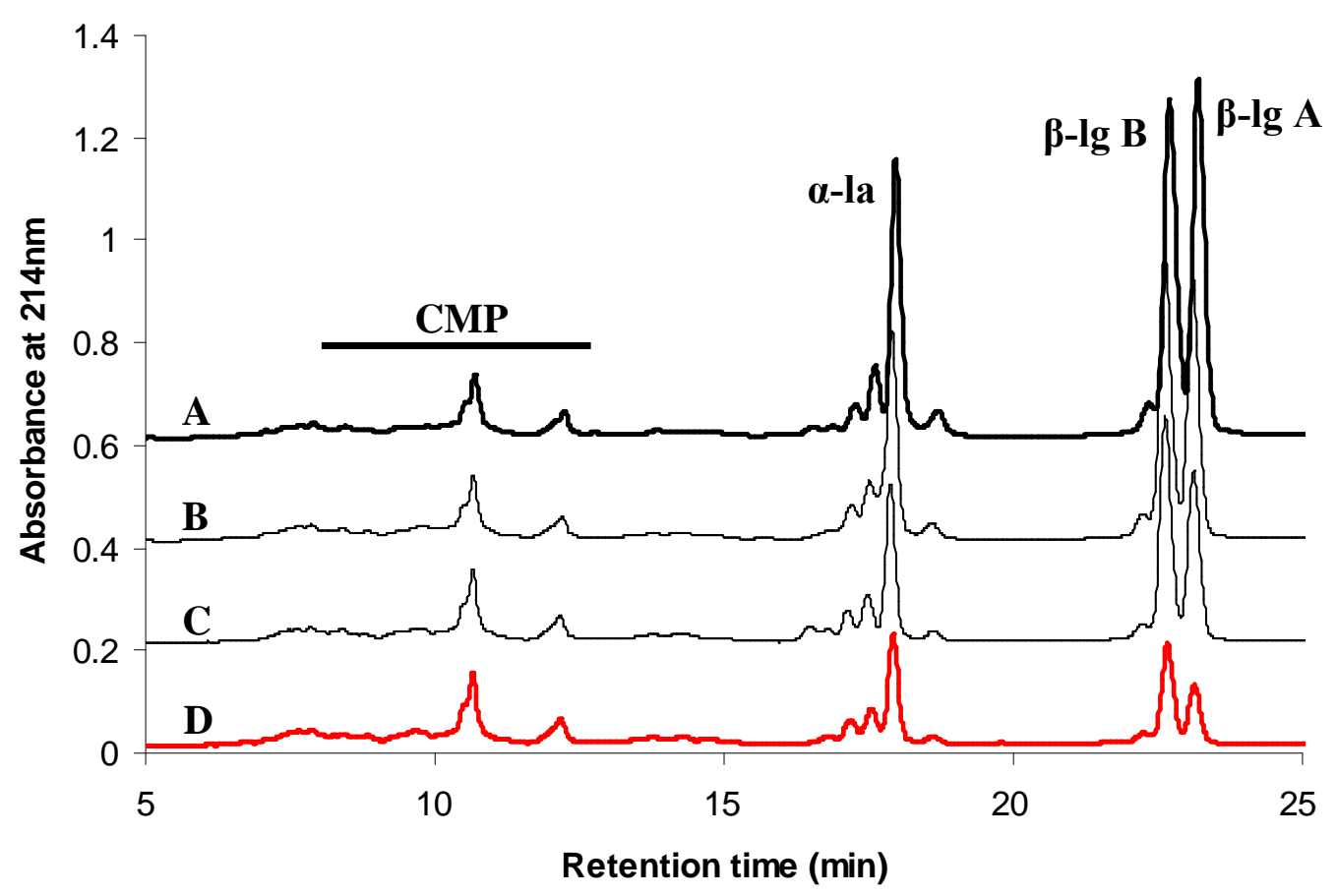




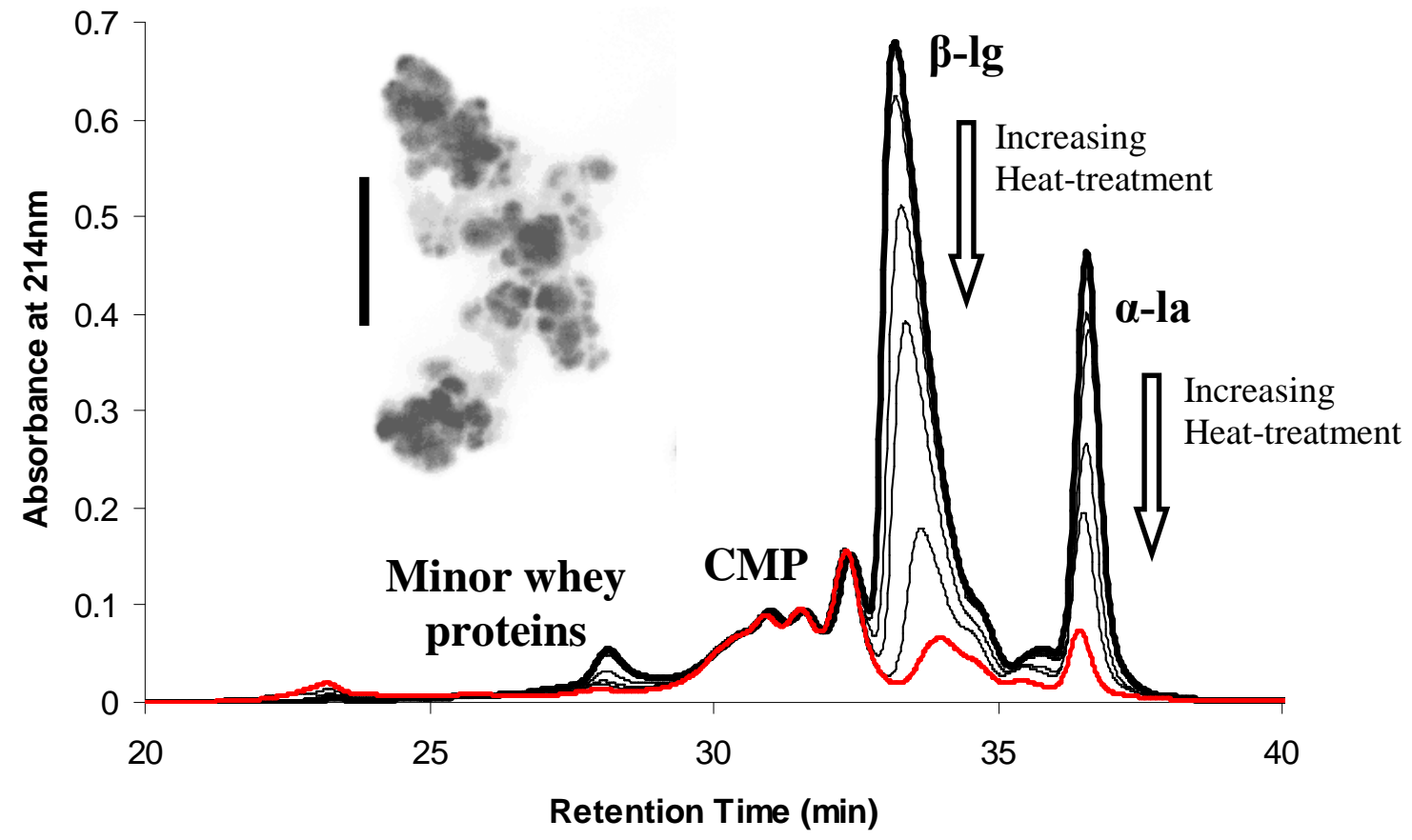


Figure 4

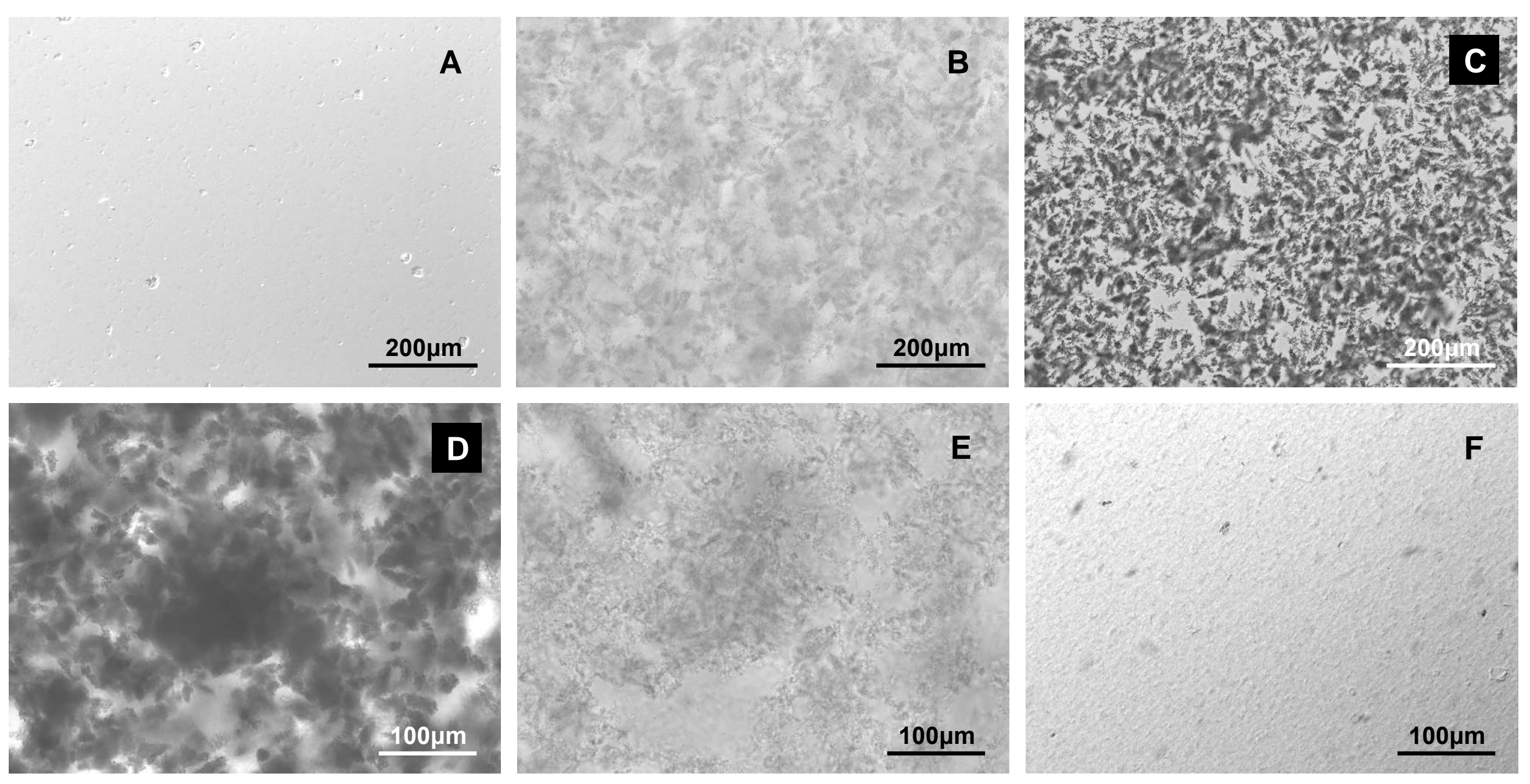

FINAL revised WORD version of O'Loughlin et al (2012). JAFC 60(19), 4895-4904. DOI: 10.1021/jf205213n 
Figure 5

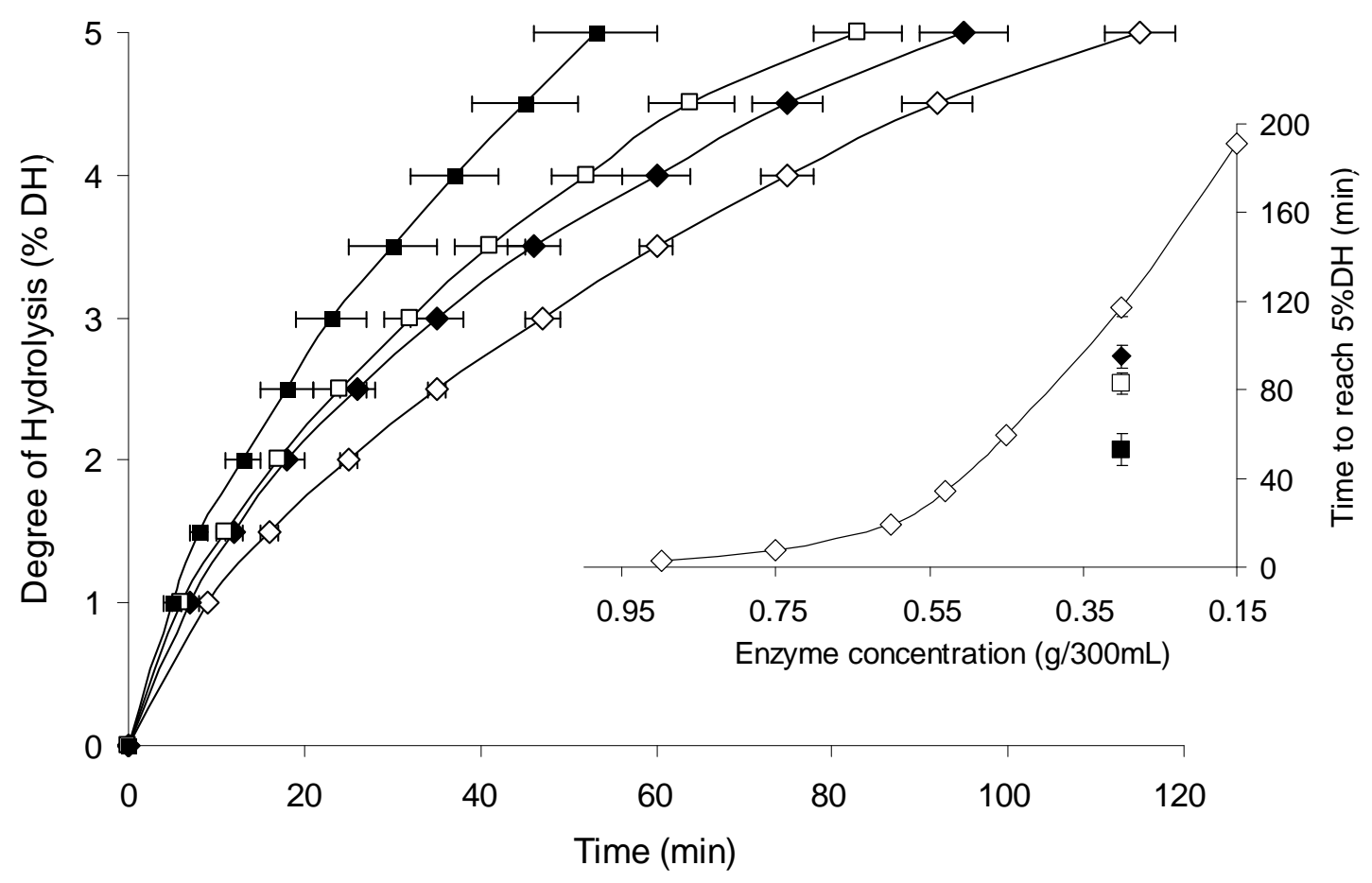


Figure 6 (intended for colour reproduction on-line and in print)
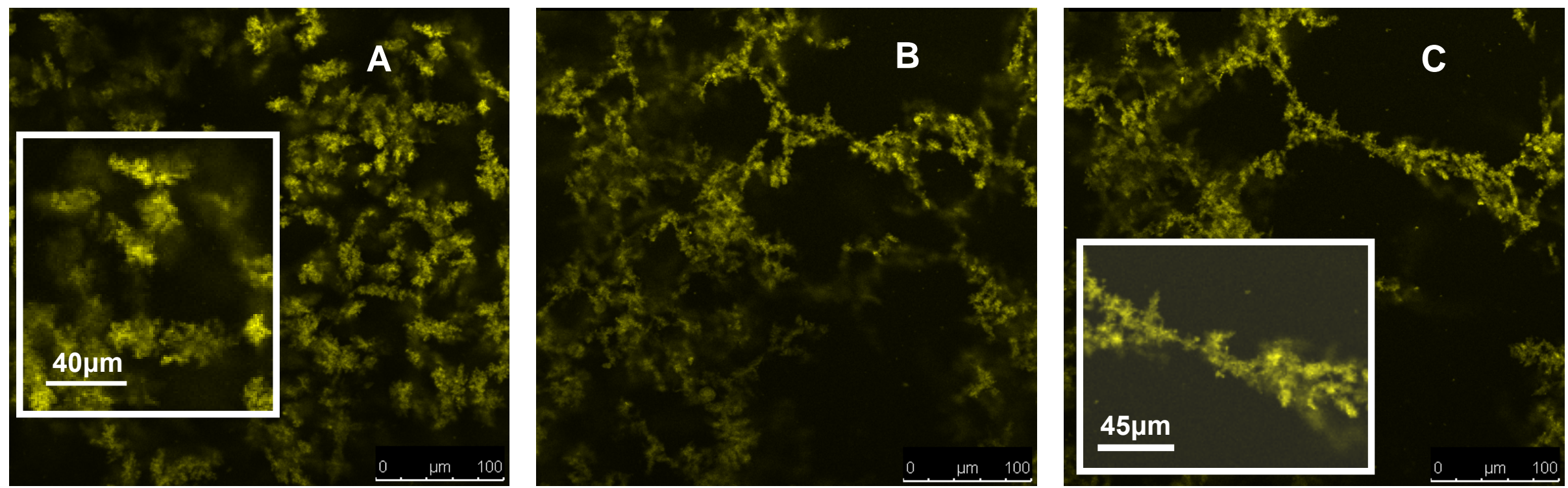